\title{
SOLAR ENERGY SYSTEM PERFORMANCE EVALUATION - SEASONAL REPORT FOR IBM SYSTEM 2, TOGUS, MAINE
}

Prepared by

\section{BM Corporation}

Federal Systems Division

150 Sparkman Drive

Huntsville, Alabama 35805

Under Contract NAS8-32036

National Aeronautics and Space Administration

George C. Marshall Space Flight Center, Alabama 35812

For the U. S. Department of Energy

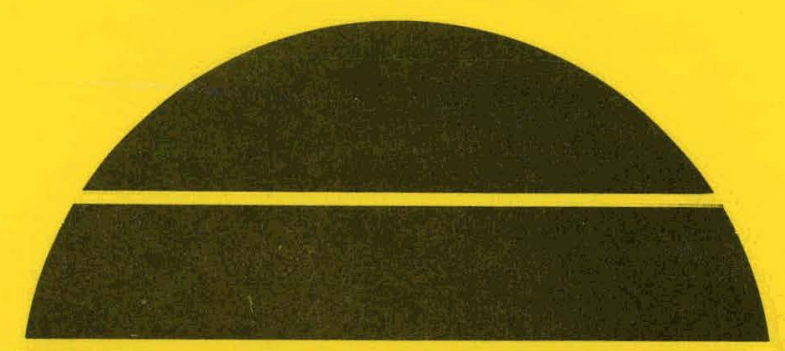

\section{U.S. Department of Energy}




\section{DISCLAIMER}

This report was prepared as an account of work sponsored by an agency of the United States Government. Neither the United States Government nor any agency Thereof, nor any of their employees, makes any warranty, express or implied, or assumes any legal liability or responsibility for the accuracy, completeness, or usefulness of any information, apparatus, product, or process disclosed, or represents that its use would not infringe privately owned rights. Reference herein to any specific commercial product, process, or service by trade name, trademark, manufacturer, or otherwise does not necessarily constitute or imply its endorsement, recommendation, or favoring by the United States Government or any agency thereof. The views and opinions of authors expressed herein do not necessarily state or reflect those of the United States Government or any agency thereof. 


\section{DISCLAIMER}

Portions of this document may be illegible in electronic image products. Images are produced from the best available original document. 
MOIICE

This report was prepared so document work sponsored by the United States Government. Netther the Unfted States nor trs agents the Unfted States Department of Energy, the United States National Aeronautics and Space Adridaseration, nor any federal employee, not any of thal: contractors, subcontractors or the1r employees, wake any wartanty, expresa or implied, or assume any lega? 114DIlizy or raaponsibility for the accuracy, completeness, ox tisafulness of any 1nformation, apparatus, product or procase fisclosed, or represent that its use would not infringe privately owned rights. 


\begin{tabular}{|c|c|}
\hline $\begin{array}{l}\text { 1. REPORT NO. } \\
\text { DOE/NASA CR-161383 }\end{array}$ & 3. RECIPIENT'S CATALOG NO. \\
\hline \multirow{2}{*}{$\begin{array}{l}\text { 4. TITLE AND SUBTITLE } \\
\text { Solar Energy System Performance Evaluation - Seasonal Report } \\
\text { for IBM System 2, Togus, Maine }\end{array}$} & $\begin{array}{l}\text { 5. REPORT DATE } \\
\text { Janua ry } 1980\end{array}$ \\
\hline & 6. PERFORMING ORGANIZATION CCIDE \\
\hline 7. AUTHOR(S) & 8. PERFORMING ORGANIZATION REPORT $\#$ \\
\hline \multirow{3}{*}{$\begin{array}{l}\text { 9. PERFORMING ORGANIZATION NAME AND ADDRESS } \\
\text { IBM Federal Systems Division } \\
\text { 150 Sparkman Drive } \\
\text { Huntsville, Alabama } 35805\end{array}$} & 10. WORK UNIT NO. \\
\hline & $\begin{array}{l}\text { 11. CONTRACT OR GRANT NO. } \\
\text { NAS8-32036 }\end{array}$ \\
\hline & 13. TYPE OF REPOR $T$ \& PERIOD COVERED \\
\hline \multirow{2}{*}{$\begin{array}{l}\text { 12. SPONSORING AGENCY NAME AND ADORESS } \\
\text { National Aeronautics and Space Administration } \\
\text { Washington, DC } 20546\end{array}$} & $\begin{array}{l}\text { Contractor Report } \\
\text { May.1978 - April } 1979\end{array}$ \\
\hline & 14. SPONSORING. AGENCY CODE \\
\hline
\end{tabular}

This work was done under the technical management of Mr. Cecil W. Messer, George C. Marshall Space Flight Center, Alabama.

16. AESTRACT

This report has been developed for the George C. Marshall Space Flight Center as a part of the Solar Heating and Cooling Development Program funded by the Department of Energy. It is one of a series of reports describing the operational and thermal performance of a variety of solar systems installed in Operational Test Sites under this program. The analysis used is based on instrumented system data monitored and collected for at least one full sea son of operation. The objective of the analysis is to report the long-term field performance of the installed system and to make technical contributions to the definition of techniques and requirements for solar energy system design.

The solar energy system, SIMS Prototype System 2, was designed by IBM to supply domestic hot water to single-family residences. The system consists of flat plate collectors, silicone working fluid, storage tank, pumps, heat exchanger, controls, and associated plumbing.

\section{MASTER}

\begin{tabular}{|l|l|l|l|}
\hline 17. KEY WOROS & $\begin{array}{c}\text { 18. DISTRIBUTION STATEMENT UC-59C } \\
\text { Unclassified-Unlimited }\end{array}$ \\
\hline $\begin{array}{c}\text { 19. SECURITY CLASSIF. (of thin roport) } \\
\text { Unclassified }\end{array}$ & $\begin{array}{c}\text { 20. SECURITY CLASSIf. (of this page) } \\
\text { Unclassified }\end{array}$ & $\begin{array}{c}\text { 21. No. OF PAGES } \\
69\end{array}$ & $\begin{array}{c}\text { 22. PRICE } \\
\text { NTIS }\end{array}$ \\
\hline
\end{tabular}


THIS PAGE

\section{WAS INTENTIONALLY LEFT BLANK}


1.

2.1

2.2

3.

3.1

3.2

3.2 .1

3.2 .2

3.2 .3

4.

5.

6.

7.

8.

APPENDIX A
2.

FOREWORD .

SYSTEM DESCRIPTION

TYPICAL SYSTEM OPERATION.

SYSTEM OPERATING SEQUENCE ............. 8

PERFORMANCE ASSESSMENT ................ 10

SYSTEM PERFORMANCE. ............... . . 11

SUBSYSTEM PERFORMANCE . . . . . . . . . . 18

COLLECTOR ARRAY SUBSYSTEM. . . . . . . . . . 19

STORAGE SUBSYSTEM. . . . . . . . . . . . . 34

HOT WATER SUBSYSTEM. ............. 37

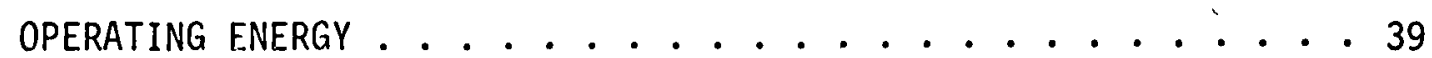

ENERGY SAVINGS .......................... 41

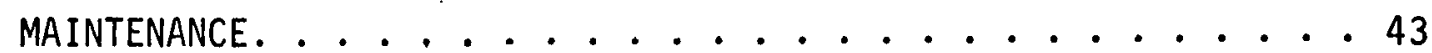

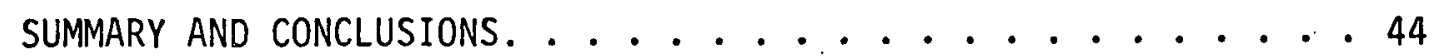

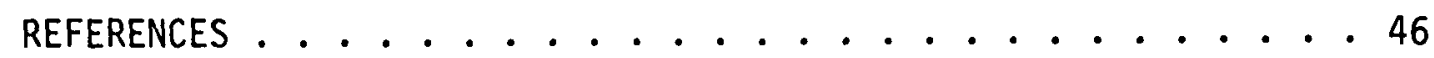

. . . . . .

APPENDIX B SOLAR ENERGY SYSTEM PERFORMANCE EQUATIONS. . ........ B-

APPENDIX $C$ LONG TERM AVERAGE WEATHER CONDITIONS ............. .1

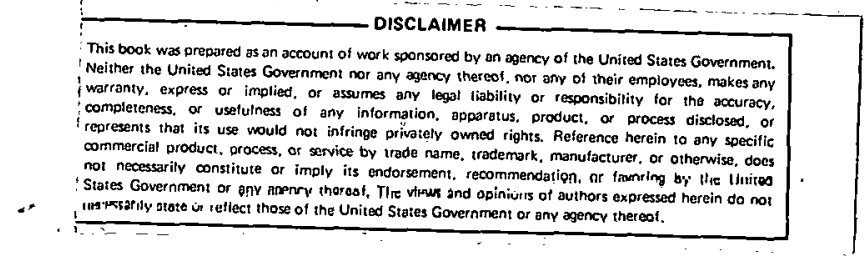


IBM-System 2 Schematic . . . . . . . . 4 IBM-System 2 Pictorial . . . . . . . . 5 Typical System Operating Parameters ... . . . 7 Typical System Operating Sequence . . . . . . 9 Solar Energy System Evaluation Block Diagram. . . 13 Collector Array Schematic . . . . . . . . 20 Collector Efficiency Curves . . . . . . . . 27 Operating Puint Histograms for Typical

Winter and Summer Months ........ 32

TABLE

System Performance Summary. . . . . . . . 16 Collector Array Performance . . . . . . . . 21 Energy Gain Comparison. . . . . . . . . . 29 Storage Subsystem Performance ... . . . . 35 Hot Water Subsystem Performancc . . . . . . . 38 Operating Energy. . . . . . . . . . . 40 
1. FOREWORD

The Solar Energy System Performance Evaluation - Seasonal Report has been developed for the George' $C$. Marshall Space Flight Center as a part of the Solar Heating and Cooling Development Program funded by the Department of Energy. The analys is contained in this document describes the technical performance of an Operational Test site (OTS) functioning throughout a specified period of time which is typically one season. The objective of the analys is is to report the long-term performance of the installed system and to make technical contributions to the definition of techniques and requirements for solar system design.

The contents of this document have been divided into the following topics of discussion:

- System Description

- Performance Assessment

- Operating Energy

- Energy Savings

- Maintenance

- Summary and Conclusions

Data used for the seasonal analyses of the Operational Test Site described in this document have been collected, processed and maintained under the (OTS) Development Program and have provided the major inputs used to perform the long-term technical assessment. 
The Seasonal Report document in conjunction with the Final Report for each Operational Test Site in the Development Program culminates the technical activities which began with the site selection and instrumentation system design in April 1976. The Final Report emphasizes the economic analysis of solar systems performance and features payback performance based on life cycle costs for the same solar system in various geographic regions. Other documents specifically related to this system are References [1], [2] and [3].*

*Numbers in brackets designate references found in Section 8. 
The IBM-System 2 Solar Energy System is located in a single-family dwelling at the Veterans Administration Center in Togus, Maine. The system is designed to preheat approximately $56 \%$ of the domestic hot water. Silicon fluid is circulated through a 105 square-foot LibbeyOwens-Ford (L.O.F.) flat-plate collector array, and a double wall heat exchanger. The collector array faces 15 degrees west of due south, at an angle of 45 degrees from the horizontal. Water from the 120gallon preheat tank is circulated through the other side of the heat exchanger. The preheat tank services a standard electric 40-gallon domestic hot water (DHW) heater, which adds the necessary auxiliary energy. Figure 2-1 is a schematic of the system. Sensor designations are in accordance with NBS-IR-76-1137 [4]. The measurement symbol prefixes: $W, T, E P$, and I represent respectively: flow rate, temperature, electric power, and insolation. Figure 2-2 is pictorial views of the installation. This system has only one mode of operation.

Mode 1-Collector-to-Preheat Tank: The system turns on when the collector outlet temperature becomes approximately $25^{\circ} \mathrm{F}$ above the temperature of water in the bottom of the preheat tank, and turns off when this delta $T$ falls below $8^{\circ} \mathrm{F}$. 
$\triangle$

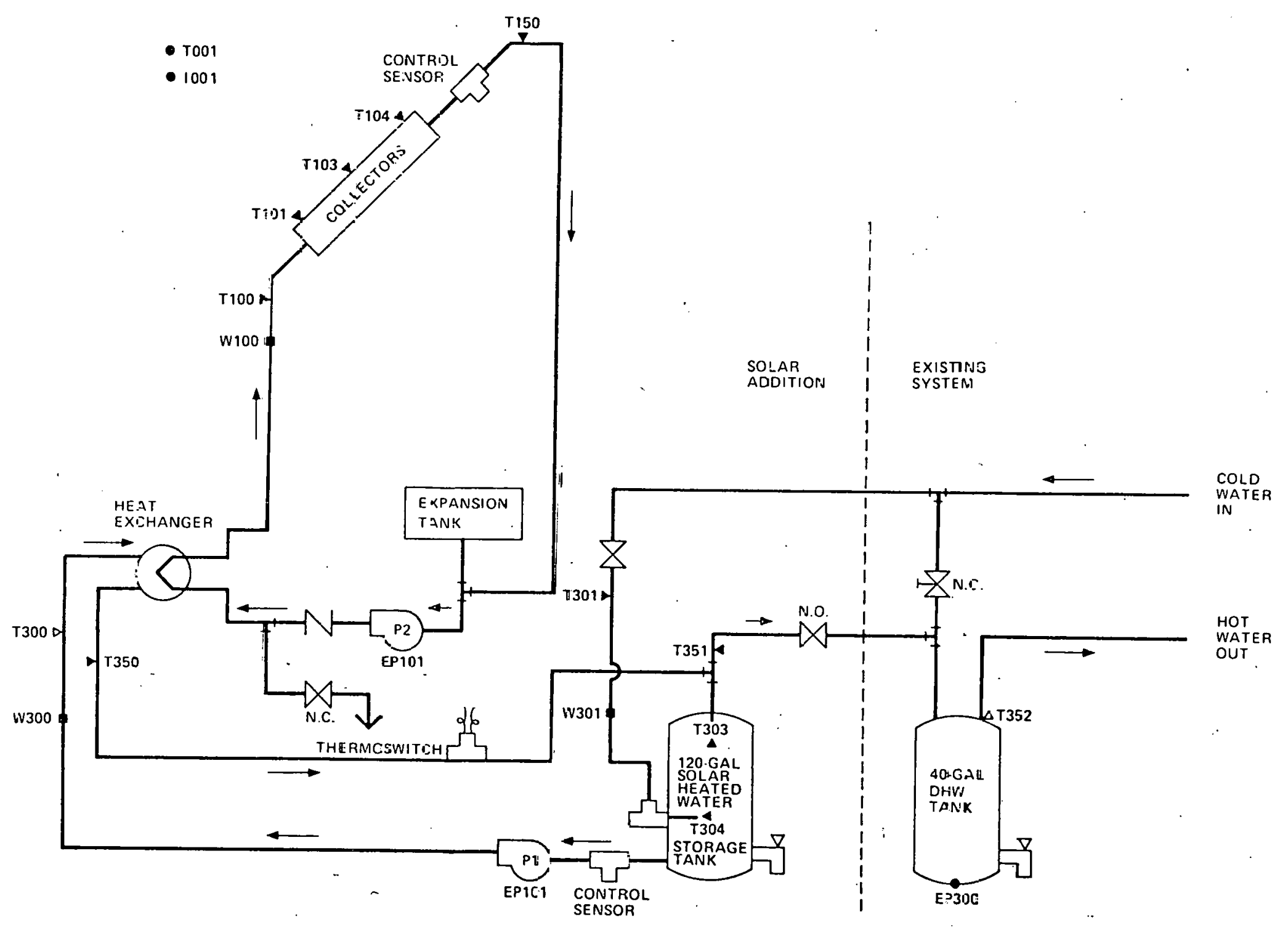

Figure 2-1. IBM-System 2 Schematic 


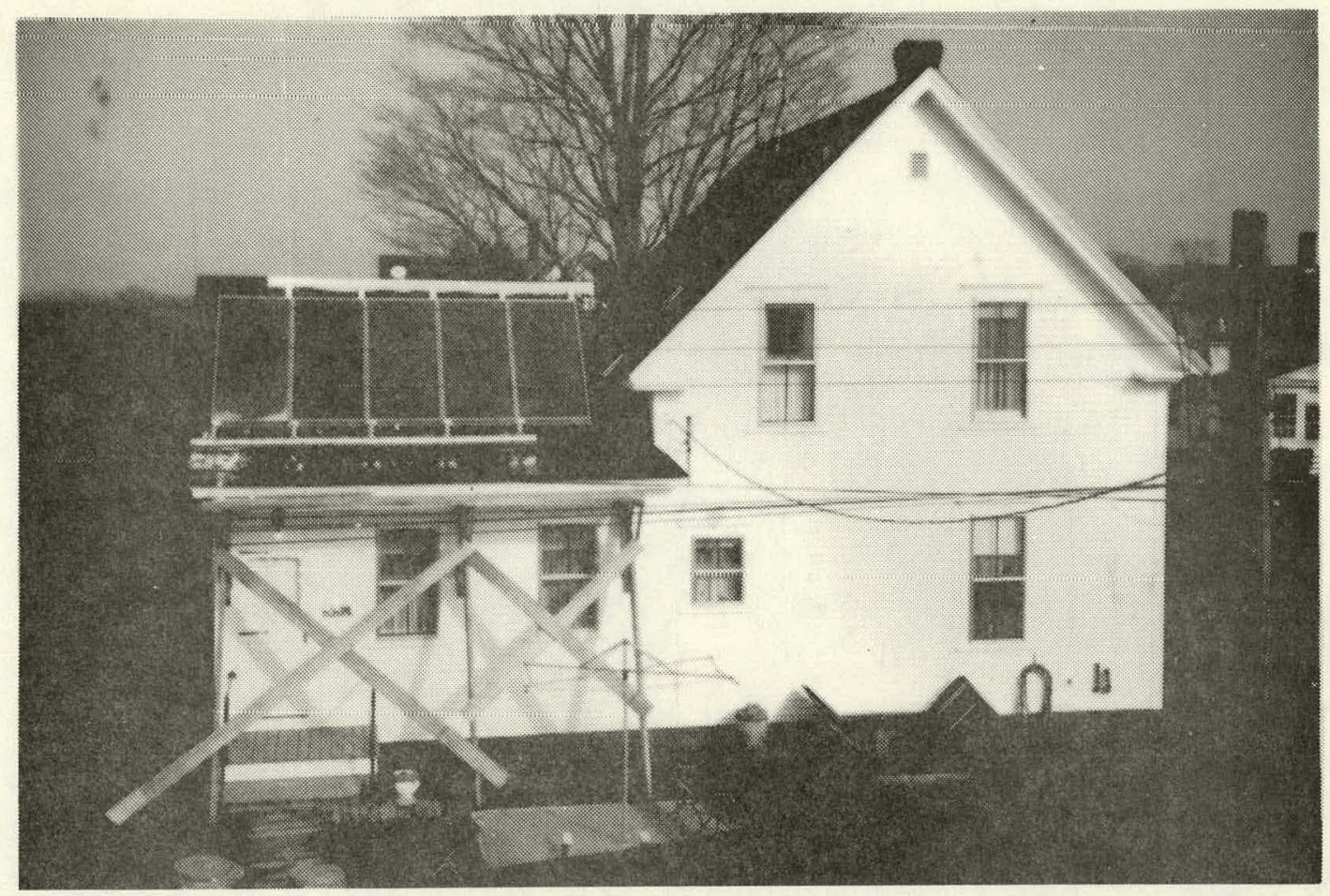

Collector Array During Installation

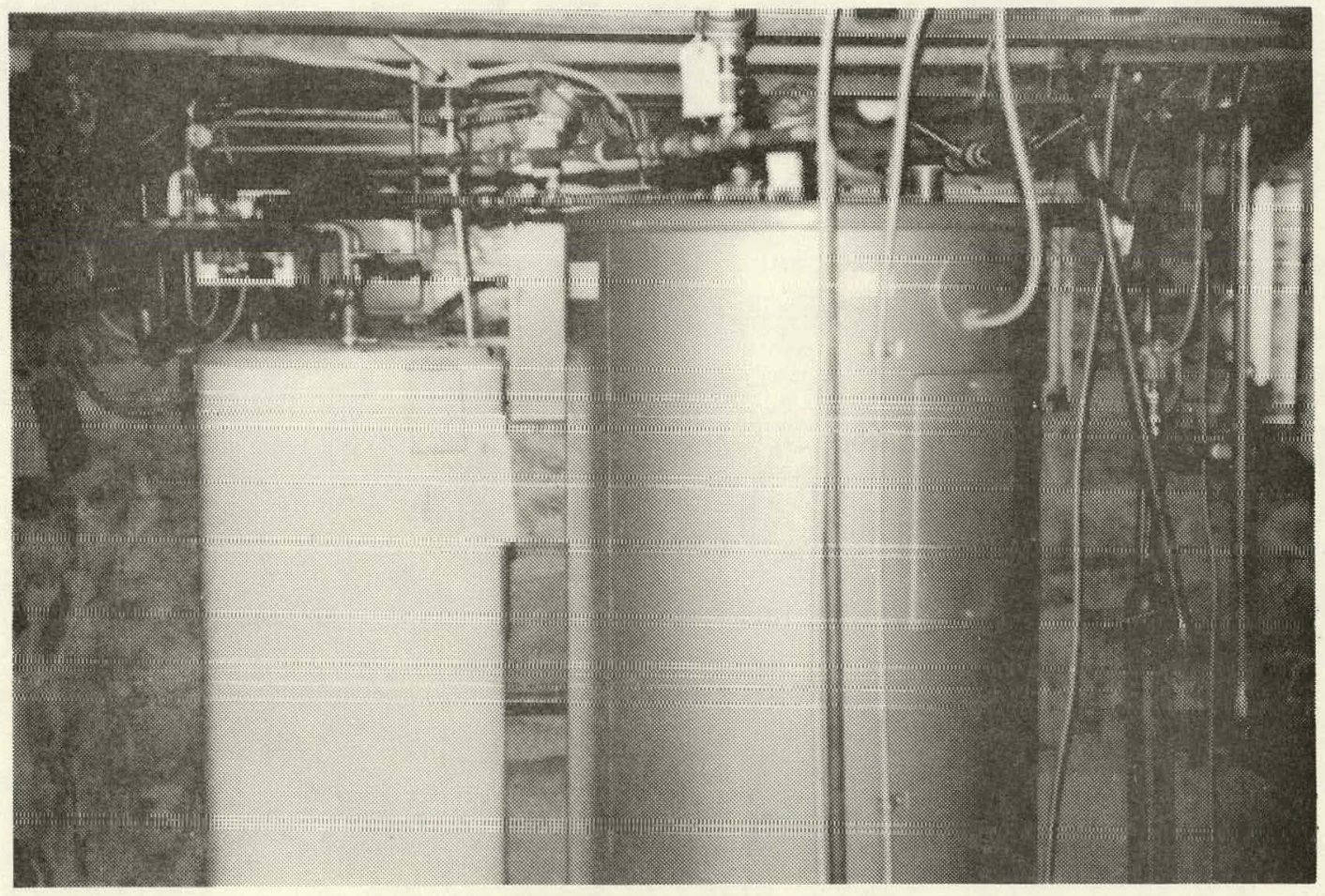

DHW Heater and Preheat Tank in Basement

Figure 2-2 IBM System 2 Pictorial 


\section{$2.1 \quad$ Typical System Operation}

Figure 2.1-1, Typical System Operating Parameters, shows data from April 8, 1979. These clear day data plots were selected to show system operation. On partly cloudy days the system may cycle on and off several times and on cloudy days the system may not turn on at a11.

Figure ? 1-1(a) shows the day's insolaliun. The twn lines mark system start up at approximate 7 y:18 and shut down at 3:15. The outside temperature was approximately $33^{\circ} \mathrm{F}$ at start up and approximately $45^{\circ} \mathrm{F}$ at shut off.

The collector loop cycled on and off at approximately 8:35, came on again at 9:18 and remained on unti1 3:15 in the afternoon. During the six hours the collector loop operated, an average of 6.1 gallons per minute of silicone fluid was pumped through the collectors. Approximately 64,000 Btu of solar energy was delivered to the domestic hot water.

Fiqure 2.1-1(h) shows collector inlct and outlet temperdlure and Figure 2.1-1(c) shows the 120 gallon preheat tank temperature and the temperature of the water from the bottom of the preheat tank at the heat exchanger inlet. At 9:18 the collector nut.let temperature was approxi mately 25 degrees above the temperature in the bottom of the preheat tank. At system shutoff $(3: 15)$ the collector outlet had dropped to approximately eighl clegrees above the preheat tank temperature.

Forty-five gallons of hot water were used at the site on April 8 with most of the usage occurring after 4:00 PM. An average day's usage for the sitc was 50 galluns with over 100 gallons per day used four or five times a month. Three people occupied the house most of the time; therefore, the usage averaged 18.7 gallons per day per person. 

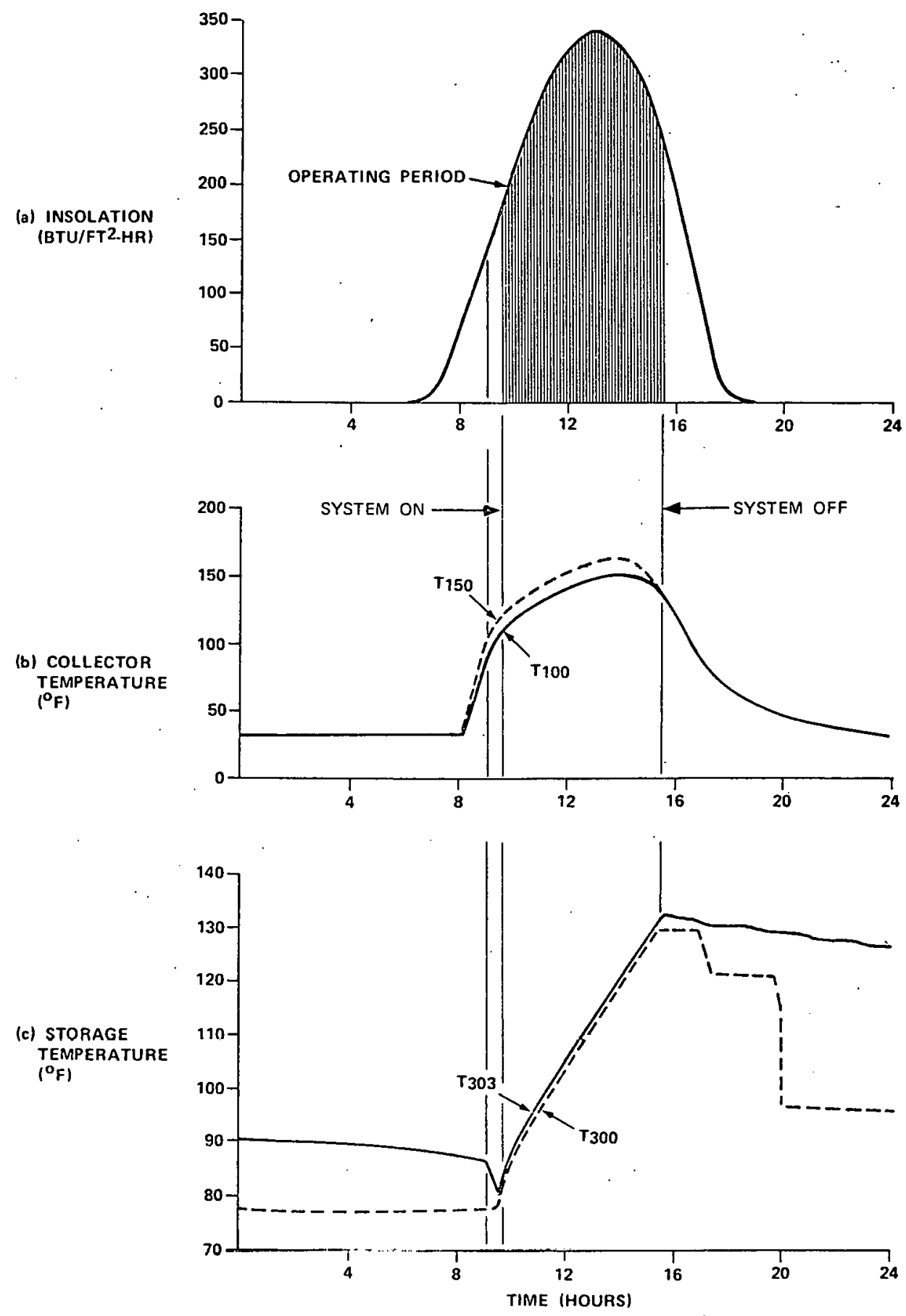

Figure 2.1-1. Typical System Operating Parameters 


\section{$2.2 \quad$ System Operating Sequence}

The Apri1 8, 1979 data were also used to show operating sequence, Figure 2.2-1. The collector loop and storage charging loop ran simultaneously with one pump circulating the silicone fluid through the collectors and heat exchanger and another pump circulating water from the preheat tank. Hot water was used off and on from 6:00 AM until almost midnight. The auxiliary heating element in the DHW heater was required 12 times during the day to keep the tank at $134^{\circ} \mathrm{F}$. Most of the aux 11 lary eneryy required was to make up tank losses since the preheat tank was supplying the DHW heater with $100^{\circ} \mathrm{F}$ to $134^{\circ} \mathrm{F}$ water. During the day $66,000 \mathrm{Btu}$ were collected, $64,000 \mathrm{Btu}$ were placed in storage, and $30,000 \mathrm{Btu}$ of solar were supplied to the DHW heater. 


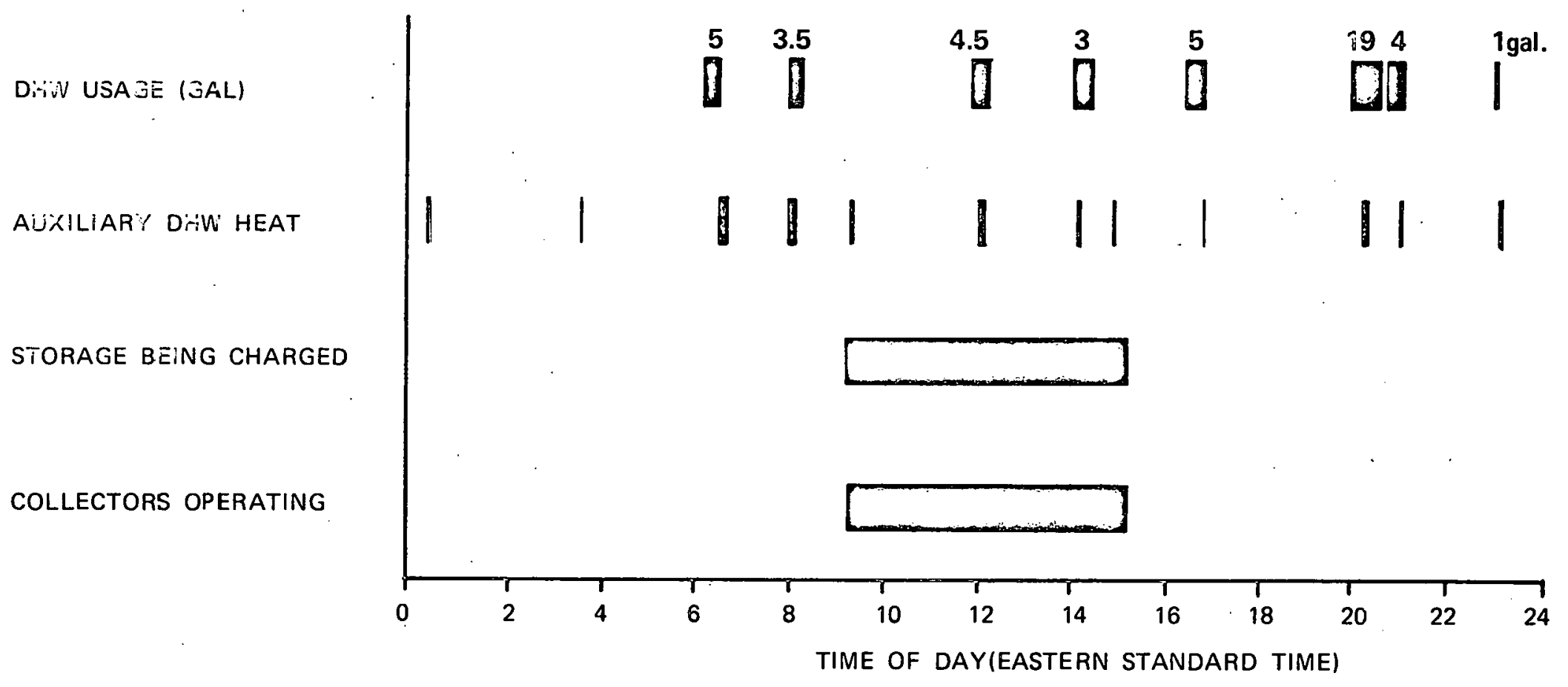

๑ Figure 2.2-1 Operating Sequence - April 8, 1979 


\section{PERFORMANCE ASSESSMENT}

The performance of the IBM System 2 Solar Energy System has been evaluated for the May 1978 through April 1979 time period from two perspectives. The first was the overall system view in which the performance values of system solar fraction and net energy savings were evaluated against the prevailing and long term average climatic conditions and system loads. The second view presents a more in depth look at the performance of the individual subsystems. Details rciating to the performance of the systeph are presented first in Section 3.1 followed by the subsystem assessment in Section 3.2 . 
This Seasonal Report provides a system performance evaluation summary of the operation of the IBM-System 2 Solar Energy System located in Togus, Maine. This analysis was conducted by evaluation of measured system performance against the comparison of measured climatic data with long-term average climatic conditions. The performance of the system is evaluated by calculating a set of primary performance factors which are based on those proposed in the intergovernmental agency report, "Thermal Data Requirements and Performance Evaluation Procedures for the National Solar Heating and Cooling Demonstration Program" [4]. The performance of the major subsystems is also evaiuated in subsequent sections of this report.

IBM System 2 was tested at the MSFC Solar Test Facility during September and October 1977 prior to installation in Togus, Maine in November 1977. The objectives of the MSFC test were to verify system operation and performance and provide a data base for comparison with Togus data. For additional information on the system 2 test refer to Reference [9].

System 2, as installed in Togus, Maine, was the same hardware that was tested with the exception of piping. Relatively long piping runs were required in the collector loop at Togus. To assure adequate flow in this loop 1.0 inch copper tubing with a minimum of bends was used. As a result of the larger tubing and cleaner piping runs, the collector loop flow rate increased from a maximum of $5.0 \mathrm{GPM}$ to $6.5 \mathrm{GPM}$. This increase in collector fluid flow allowed the Togus system to operate more efficiently than the test system. A comparison of IBM System 2 (Togus) and test collector efficiencies is shown in Section 3.2.1.

The measurement data were collected for the period May 1978 through Apri1 1979. Systein perfurmalice data were provided through an IBM deve1oped Central Data Processing System (CDPS) [5] consisting of a remote Site Data Acquisition System (SDAS), telephone data transmission lines and couplers, an IBM System 7 computer for data management, and an IBM System 370/145 computer for data processing. The CDPS supports the collection and analysis of solar data acquired from instrumented systems 
located throughout the country. These data are processed daily and summarized into monthly performance formats which form a common basis for comparative system evaluation. These monthly summaries are the basis of the evaluation and data given in this report.

The solar energy system performance summarized in this section can be viewed as the dependent response of the system to certain primary inputs. This relationship is illustrated in Figure 3.1-1. The primary inputs are the incident solar energy, the outdoor ambient temperature and the system load. The dependent responses of the system are the system solar fraction and the total energy savings. Both the input and output definitions are as follows:

\section{Inputs}

- Incident solar energy - The total solar energy incident on the collector array available for collection.

- Ambient temperature - The temperature of the external environment which affects both the energy that can be collected and the eriergy demland.

- System load - The loads that the system is designed to meet, which are affected by the life style of the user (space heating/cooling domestic hot water, etc., as appliçạblẹ).

Outputs

- System solar fraction - The ratio of solar energy applied to the system loads to total energy (solar plus auxiliary energy) required by the loads. 


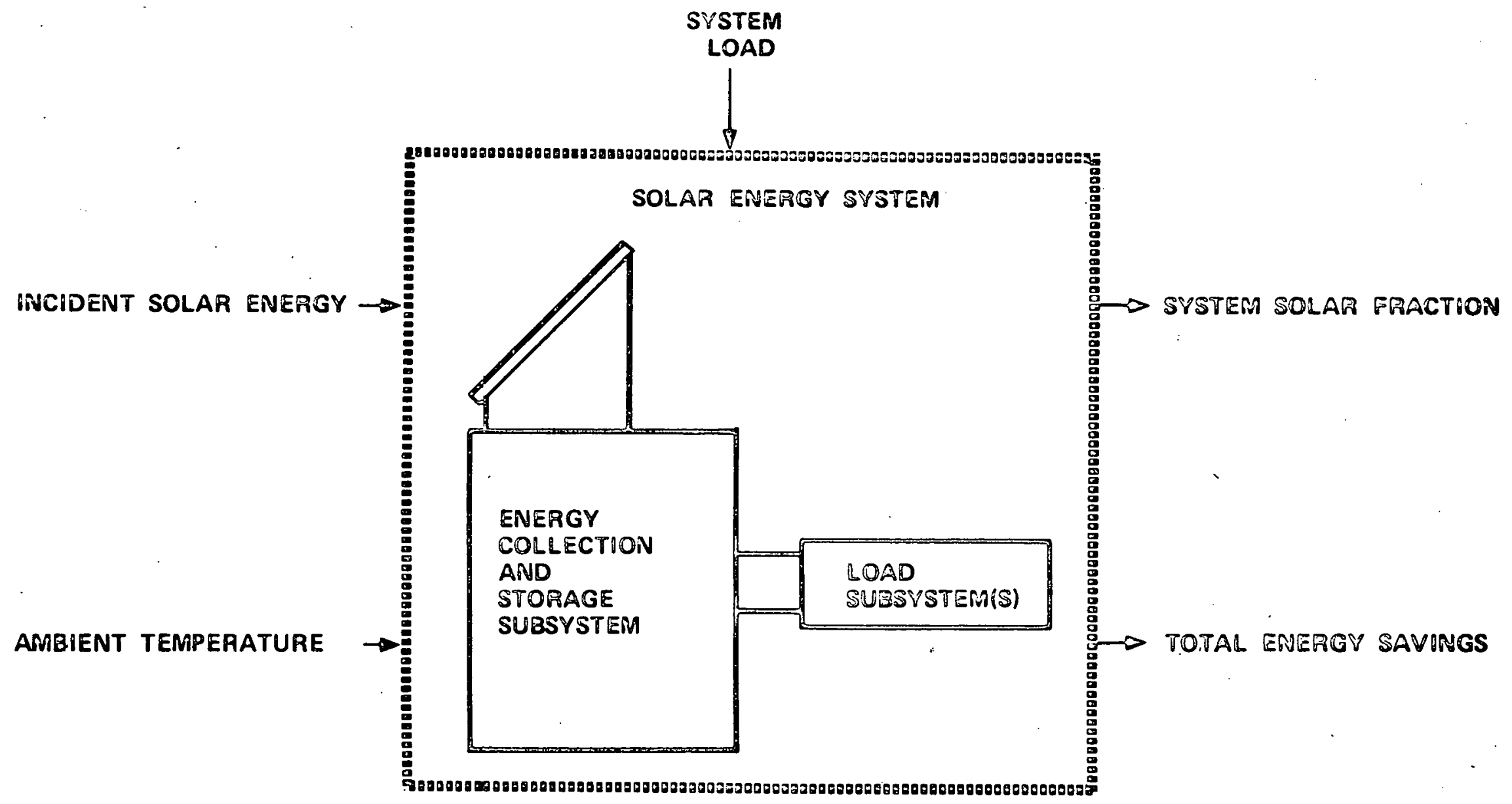

Figure 3.1-1: Solar Energy System Evaluation Block Diagram 
- Total energy savings - The quantity of auxiliary energy (electrical or fossil) displaced by solar energy.

The monthly values of the inputs and outputs for the total operational period are shown in Table 3.1-1, the System Performance Summary. Comparative long term average values of daily incident solar energy, and outdoor ambient temperature are given for reference purpose. The long term data are taken from Reference 1 of Appendix C: Generally the solar energy system is designed to supply an amount of energy that results in a desired value of system solar fraction while operatina under climatic conditions that are defined by the long term average value of daily incident solar energy and outdoor ambient temperature. If the actual climatic conditions are close to the long term average values, there is little adverse impact on the system's ability to meet design goals. This is an important factor in evaluating system performance and is the reason the long term average values are given. The data reported in the following paragraphs are taken from Table 3.1-1.

At the IBM System 2 site for the twelve month report period, the long term average daily incident solar energy in the plane of the collector was $1,476 \mathrm{Btu} / \mathrm{ft}^{2}$. The average daily measured value was $1,313 \mathrm{Btu} / \mathrm{ft}^{2}$ which is about 11 percent below the long term value. On a monthly basis, January 1979 was the worst month with an average daily measured value of incident solar energy 45 percent below the long term average monthly value. February 1979 was the best month with an average daily measured value 6 percent above the long term average monthly value. On a long term basis it is obvious that the good and bad months average out so that the long teerm average performanse shnuld not. he adversely influpenced hy small differences between measured and long term average incident solar energy.

The outdoor ambient temperature influences the operation of the solar energy system in two important ways. First the operating point of the 
collectors and consequently the collector efficiency or energy gain is determined by the difference in the outdoor ambient temperature and the collector inlet temperature. This will be discussed in greater detail in Section 3.2.1. Secondly the load is influenced by the outdoor ambient temperature. The long term average daily ambient temperature was $45^{\circ} \mathrm{F}$ for the IBM System 2 site which agrees with the measured value of $45^{\circ} \mathrm{F}$.

The system load was very consistent over the year averaging $1.22 \mathrm{mil}$ lion Btu per month. The only months when the load was less than 1 million Btu were June and August. During each of these months the house was unoccupied for a week. For the months when the house was occupied, the average daily hot water used was 60 gallons per day. For the full year the average daily usage was 56 gallons per day. The average supply water temperature for the year was $52^{\circ} \mathrm{F}$ with final hot water temperature averaging $134^{\circ} \mathrm{F}$. The average temperature rise for the hot water was therefore $82^{\circ} \mathrm{F}$.

Also presented in Table 3.1-1 are the measured and expected values of system solar fraction where system solar fraction is the ratio of solar energy applied to system loads to the total energy (solar plus auxiliary) applied to the loads. The expected values have been derived from a modified f-Chart analysis which uses measured weather and subsystem loads as inputs ( $f$-Chart is the designation of a procedure that was developed by the Solar Energy Laboratory, University of Wisconsin, Madison, for modeling and designing solar energy systems [8]). The mudel used in the analysis is based on manufacturers' data and other known system parameters. The bases for the model are empirical correlations developed for liquid and air solar energy systems that are presented in graphical and equation form and referred to as the f-Charts where ' $f$ ' is a designator for the system solar fraction. The output of the f-Chart procedure is the expected system solar fraction. The 
TABLE 3.1-1

SYSTEM PERFORMANCE SUMMARY

IBM SYSTEM 2

\begin{tabular}{|c|c|c|c|c|c|c|c|c|}
\hline \multirow[b]{2}{*}{ Month } & \multicolumn{2}{|c|}{ 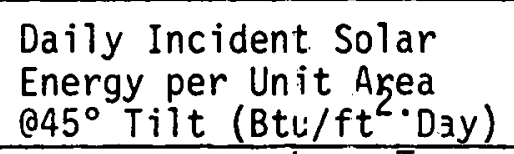 } & \multicolumn{2}{|c|}{$\begin{array}{c}\text { Anbient } \\
\text { Temperature } \\
{ }^{\circ} \mathrm{F}\end{array}$} & \multirow{2}{*}{$\begin{array}{c}\text { System } \\
\text { Load- } \\
\text { Measured } \\
\text { (Million Btu) }\end{array}$} & \multicolumn{2}{|c|}{$\begin{array}{l}\text { Solar } \\
\text { Fraction } \\
\text { (Percent) }\end{array}$} & \multirow{2}{*}{$\begin{array}{c}\text { Total : } \\
\text { Energy } \\
\text { Savings } \\
\text { (Million Btu) }\end{array}$} \\
\hline & Measured & $\begin{array}{r}\text { Long Term } \\
\text { Avera.je } \\
\end{array}$ & Measured & $\begin{array}{c}\text { Long Term } \\
\text { Average } \\
\end{array}$ & & Measured & Expected & \\
\hline May 78 & 1,654 & 1,674 & 59 & 52 & 1.55 & 46 & 57 & 0.93 \\
\hline Jun 78 & 1,467 & 1,623 & 64 & 63 & 0.87 & 48 & 70 & 0.57 \\
\hline Jul 78 & 1,665 & 1,733 & 70 & 68 & 1.11 & 58 & 69 & 0.92 \\
\hline Aug 78 & $1,5.12$ & 1,695 & 66 & 66 & 0.71 & 55 & 76 & 0.50 \\
\hline Sep 78 & 1,676 & 1,644 & 54 & 59 & 1,06 & 62 & 65 & 0.79 \\
\hline oct 78 & 1,090 & 1,496 & 49 & 48 & 1.14 & 54 & 41 & 0.66 \\
\hline Nov 78 & -- & 1,022 & -- & 39 & -- & -- & -- & -- \\
\hline Dec 78 & 994 & 1,074 & 22 & 27 & 1.32 & 46 & 23 & 0.67 \\
\hline $\operatorname{Jan} 79$ & 629 & 1,141 & 21 & 23 & 1.46 & 38 & 9 & 0.61 \\
\hline Feb 79 & 1,484 & 1,397 & 14 & 25 & 1.38 & 51 & 48 & 0.85 \\
\hline $\operatorname{Mar} 79$ & 1,087 & 1,700 & 35 & 32 & 1.62 & 49 & 33 & 0.97 \\
\hline Apr 79 & 1,240 & 1,514 & 41 & 43 & 1.20 & 50 & 49 & 0.74 \\
\hline Total & -- & -- & - & -- & $14.64^{\star}$ & -- & -- & $8.96 *$ \\
\hline Average & 1,373 & 1,476 & 45 & 45 & 1.22 & 51 & 47 & 0.75 \\
\hline
\end{tabular}

*Total values include a value for November 78 which was assumed to be equal to the Average value. 
measured value of system solar fraction was computed from measurements obtained through the instrumentation system of the energy transfers that took place within the solar energy system. These represent the actual performance of the system installed at the site.

Measured solar fraction was slightly better than expected for the year by $8.5 \%$. Solar fraction was much better than expected during the cold, cloudy months of December and January. Instrumentation was not sufficient to show how the system provided energy during this period of minimum collector loop operation. An oil-fired furnace only a few feet from the preheat tank and DHW heater is suspected of providing a warm basement ambient temperature and some directly radiated heat energy to the preheat tank and plumbing. The preheat tank in a sense had negative losses on many cold, cloudy days when solar was not available.

"Settling tanks" in basements have been used for years in northern latitudes to warm incoming water to basement ambient before it enters the DHW heater. The temperature of incoming supply water at IBM-System 2 in Togus, Maine was below $40^{\circ} \mathrm{F}$ for several days during February with the basement temperature generally above $70^{\circ} \mathrm{F}$. This additional energy could not be separated from the pure solar energy and was, therefore, included as shown. Typically 20 percent of the tank energy was lost during the summer operation.

Total energy savings is the tinal column in Table 3.1-1. The total energy savings for the IBM System 2 solar energy system was. 8.96 million Btu or $2625 \mathrm{kwh}$ of electrical energy for the year. The energy saved did replace expensive, conventional energy. The system did save enough energy to cover both the cost of its own operation and begin to repay the initial investment. 


\subsection{Subsystem Performance}

The IBM-System 2 solar energy installation may be divided into three subsystems:

1. Collector array

2. Storage

3. Domestic hot water

Each subsystem is evaluated by the techniques defined in Section 3 and is numerically analyzed each month for the monthly performance assessment. This section presents the results of integrating the monthly data available on the three subsystems for the period May 1978 through April 1979. 


\subsubsection{Collector Array Subsystem}

The IBM System 2 collector array consists of five LOF Model 1112 flat plate liquid collectors having a gross area of 105 square feet connected for parallel flow. The flow path through each collector panel is also parallel. The fluid used in the collector loop is Dow Corning Q2-1132 silicone. Interconnection and flow details, as well as other pertinent operational characteristics are shown in Figure 3.2.1-1. The collector subsystem analysis and data are given in the following paragraphs.

Collector array performance is described by the collector array efficiency. This is the ratio of collected solar energy to incident solar energy, a value always less than unity because of collector losses. The incident solar energy may be viewed from two perspectives. The first assumes that all available solar energy incident on the collectors be used in determining collector array efficiency. The efficiency is then expressed by the equation:

$$
n_{c}=Q_{s} / Q_{i}
$$

where

$$
\begin{aligned}
& n_{c}=\text { Collector array efficiency } \\
& Q_{s}=\text { Collected solar energy } \\
& Q_{j}-\text { Incident solar energy }
\end{aligned}
$$

The efficiency determined in this manner includes the operation of the control system. For example, solar energy can be available at the collector, but the collector absorber plate temperature may be below the minimum control temperature set point for collector loop operation, thus the energy is not collected. The monthly efficiency by this method is listed in the column entitled "Collector Array Efficiency" in Table 3.2.1-1. 


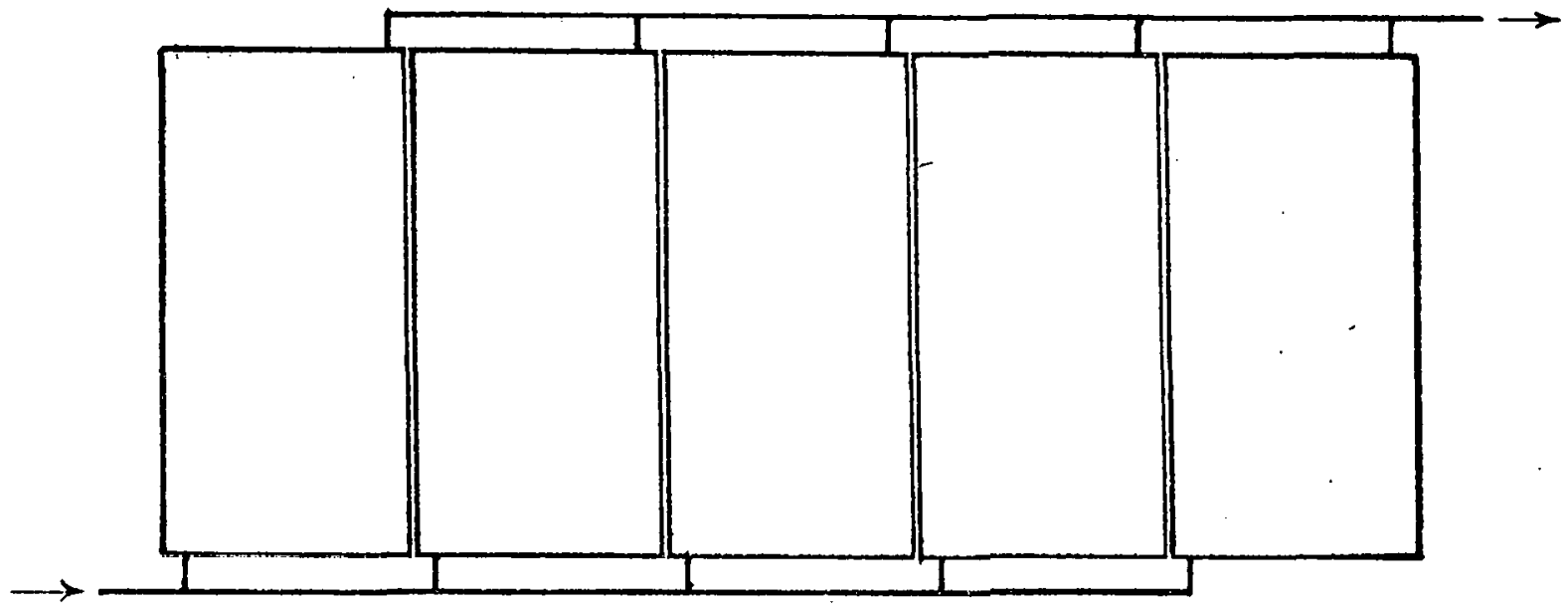

Collector Data

Manufacturer - L.O.F.

Model - 1112 (Sun Panel)

Type - Liquid

Number of Collectors - Five

Flow Path - Parallel Z Flow

G.P.M. -5.5 to 6.5 of Silicone Fluid

Site Data

Location - Togus, Maine

Latitude $=44.3^{\circ}$

Longitude $=69.7^{\circ} \mathrm{W}$

Collector Tilt $-45^{\circ}$

Azimuth - 15 Degrees West of South

Figure 3.2.1-1

Collector Array Schematic 
TABLE 3.2.1-1

COLLECTOR ARRAY PERFORMANCE

\begin{tabular}{|c|c|c|c|c|c|}
\hline Month & $\begin{array}{l}\text { Incident } \\
\text { Solar Energy } \\
\text { (Million Btu) }\end{array}$ & $\begin{array}{l}\text { Collected } \\
\text { Solar Energy } \\
\text { (Million Btu) }\end{array}$ & $\begin{array}{l}\text { Collector Array } \\
\text { Efficiency }\end{array}$ & $\begin{array}{l}\text { Cparational } \\
\text { Incident Energy } \\
\text { (Milition Btu) }\end{array}$ & $\begin{array}{l}\text { Operational } \\
\text { Collector } \\
\text { Erriciency }\end{array}$ \\
\hline May 78 & 5.38 & * & * & 2.90 & * \\
\hline Jun 78 & 4.62 & 0.92 & 0.20 & 2.37 & 0.39 \\
\hline JuT 78 & 5.42 & 1.23 & 0.23 & 3.29 & 0.37 \\
\hline Aug 78 & 4.92 & 1.01 & 0.21 & 2.72 & 0.37 \\
\hline $\operatorname{Sep} 78$ & 5.09 & 1.23 & 0.24 & 3.56 & 0.35 \\
\hline Oct 78 & 3.55 & 0.82 & 0.23 & 2.36 & 0.35 \\
\hline Nov 78 & $\star \star \star$ & $\star \star$ & ** & $\star *$ & ** \\
\hline Dec 78 & 3.23 & 0.73 & 0.23 & 2.06 & 0.35 \\
\hline Jan 79 & 2.05 & 0.35 & 0.17 & 1.12 & 0.31 \\
\hline Feb 79 & 4.36 & 0.87 . & 0.20 & 2.91 & 0.30 \\
\hline Mar 79 & 3.54 & 0.72 & 0.20 & 2.16 & 0.33 \\
\hline Apr 79 & 3.91 & 0.94 & 0.24 & 2.38 & 0.39 \\
\hline Total & 46.07 & 8.82 & -- & 27.83 & -- \\
\hline Average & 4.19 & 0.88 & 0.22 & 2.53 & 0.35 \\
\hline
\end{tabular}

* Collector inlet sensor (TrO0) bad.

** Data reduction problem precluded processing of November data. 
The second viewpoint assumes that only the solar energy incident on the collector when the collector loop is operational be used in determining the collector array efficiency. The value of the operational incident solar energy used is multiplied by the ratio of the gross collector area to the gross collector array area to compensate for the difference between the two areas caused by installation spacing. The efficiency is then expressed by the equation:

$$
n_{c o}=n_{s} /\left(Q_{0 i} \times{ }^{A_{p}} / A_{a}\right)
$$

where

$$
\begin{aligned}
n_{0}= & \text { Operational collector array efficiency } \\
Q_{S}= & \text { Collected solar energy } \\
Q_{0 i}= & \text { Operational incident solar energy } \\
A_{p}= & \begin{array}{l}
\text { Gross collector area (the product of } \\
\text { the number of collectors and the } \\
\text { envelope area of one collector) }
\end{array} \\
A_{a}= & \begin{array}{l}
\text { Gross collector array area (total area } \\
\text { including all monting and connecting } \\
\text { hardware and spacing of units) }
\end{array}
\end{aligned}
$$

The monthly efficiency computed by this method is listed in the column entitled "Operational Collector Array Efficiency" in Table 3.2.1-1.

In the ASHRAE Standard 93-77 [6] a collector efficiency is defined in the same terminology as the operational collector array efficiency. However, the ASHRAE efficiency is determined from instantaneous evaluation under tightly controlled, steady state test conditions, while the operational collector array efficiency is determined from actual dynamic conditions of daily solar energy system operation in the field. 
The ASHRAE Standard 93-77 definitions and methods often are adopted by collector manufacturers and independent testing laboratories in evaluating collectors. The collector evaluation performed for this report using the field data indicates that there was an insignificant difference between the laboratory single panel collector data and the collector data determined from long term field measurements. This is not always the case, and there are two primary reasons for differences when they exist:

- Test conditions are not the same as conditions in the field, nor do they represent the wide dynamic range of field operation (i.e. inlet and outlet temperature, flow rates and flow distribution of the heat transfer fluid, insolation levels, aspect angle, wind conditions, etc.)

- Collector tests are not generally conducted with units that have undergone the effects of aging (i.e. changes in the characteristics of the glazing material, collection of dust, soot, pollen or other foreign material on the glazing, deterioration of the absorber plate surface treatment, etc.)

Consequently field data collected over an extended period will generally provide an improved source of collector performance characteristics for use in long-term system performance definition.

The operational collector array efficiency data given in Table 3.2.1-1 are monthly averages based on instantaneous efficiency computations over the total performance period using all available data. For detailed collector analysis it was desirable to use a limited subset of the available data that characterized collector operation under "steady state" conditions. This subset was defined by applying the following restrictions: 
(1) The measurement period was restricted to collector operation when the sun angle was within 30 degrees of the collector normal.

(2) Only measurements associated with positive energy ga in from the collectors were used, i.e., outlet temperatures must have exceeded inlet temperatures.

(3) The sets of measured parameters were restricted to those where the rate of change of all parameters of interest during two regular data system intervals* was limiled to a maximum of 5 percent.

Instantaneous efficiencies $\left(\eta_{j}\right)$ computed from the "steady state" operation measurements of incident solar energy and collected solar energy by Equation (2)** were correlated with an operating point determined by the equation:

$$
x_{j}=\frac{T_{1}-T_{a}}{I}
$$
where $\quad x_{j}=\begin{aligned} & \text { Collector operating point at the } j^{\text {th }} \\ & \text { instant }\end{aligned}$

$T_{i}=$ collector inlet temperature

$T_{a}=$ Outdoor ambient temperature

$I=$ Rate of incident solar radiation

The data points $\left(n_{j}, x_{j}\right)$ were then plotted on a graph or efficiency versus operating point and a first order curve described by the slopeintercept formula was fitted to the data through linear regression techniques. The form of this fitted efficiency curve is:

*The data system intervat was 5- $1 / 3$ minutes in duration. Values of all measured parameters were continuously sampled at this rate throughout the performance period.

**The ratio $A_{p} / A_{a}$ was assumed to be unity for this analysis. 


$$
n_{j}=b-m x_{j}-
$$
where $n_{j}=$ Collector efficiency corresponding to the $j^{\text {th }}$ instant
$b=$ Intercept on the efficiency axis
$(-) m=$ Slope
$\begin{aligned} & x_{j}= \text { Collector operating point at } j^{\text {th }} \\ & \text { instant }\end{aligned}$

The relationship between the empirically determined efficiency curve and the analytically developed curve will be established in subsequent paragraphs.

The analytically developed collector efficiency curve is based on the Hottel-Whillier-Bliss equation

$$
\begin{aligned}
n & =F_{R} \tau \alpha-F_{R} U_{L}\left(\frac{T_{i}-T_{a}}{I}\right) \\
\text { where } & =\text { Collector efficiency } \\
F_{R} & =\text { Collector heat removal factor } \\
\tau & =\text { Transmissivity of collector glazing } \\
\alpha & =\text { Absorptance of collector plate } \\
U_{L} & =\text { Overall collector energy loss coefficient } \\
T_{i} & =\text { Collector inlet fluid temperature } \\
T_{a} & =\text { Outdoor ambient temperature } \\
I & =\text { Rate of incident solar radiation }
\end{aligned}
$$


The correspondence between equations (4) and (5) can be readily seen. Therefore by determining the slope-intercept efficiency equation from measurement data, the collector performance parameters corresponding to the laboratory single panel data can be derived according to the following set of relationships:

$b=F_{R}{ }^{\tau \alpha}$
and
$m=F_{R} U_{L}$

where the terms arc as proviously defined

The discussion of the collector array efficiency curves in subsequent paragraphs is based upon the relationships expressed by Equation (6).

In deriving the collector array efficiency curves by the linear regression technique, measurement data over the entire performance period yields higher confidence in the results than similar analysis over shorter periods. Over the longer periods the collector array is forced to operate over a wider dynamic range. This eliminates the tendency shown by some types of solar energy systems to cluster efficiency values over a narrow range of operating points. The clustering effect tends to make the linear regression technique approach constructing a line through a single data point. The use of data from the entire performance period results in a collector array efficiency curve that is more accurate in long term solar system performance prediction. The long term curve, the curve derived from the laboratory single panel data, and the MSFC test curve are shown in Figure 3.2.1-2.

The three curves of Figure 3.2.1-2 do not show the significant differences that similar analysis studies done on other collectors have shown. The slight differences in the long term field data and MSFC test curves are 


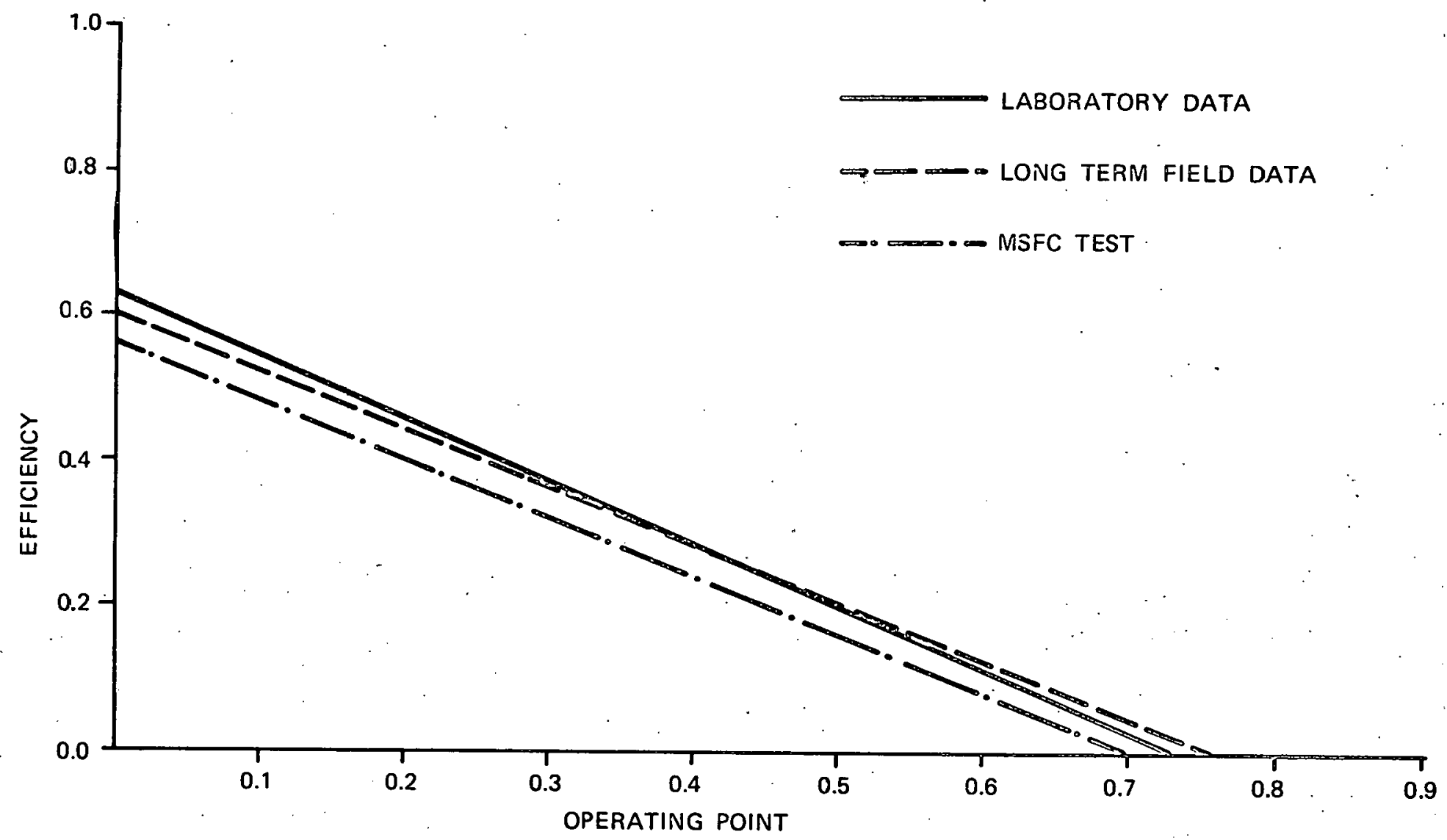

Figure 3.2.1-2 IBM System 2. Collector Êfficiency Curves 
mostly due to flow rate. The curve from MSFC testing represents data with a 4.0 to $5.0 \mathrm{GPM}$ collector array flow rate. The collector array flow rate at the Togus site ranged from 5.5 to $6.5 \mathrm{GPM}$. The test conditions for the laboratory single panel curve are not known.

Table 3.2.1-2 presents data comparing the monthly measured values of solar energy collected with the predicted performance determined from the long term regression curve and the laboratory single panel efficiency curve. The predictions were derived by the following procedure:

1. The instantaneous operating points were computed using Equation (3).

2. The instantaneous efficiency was computed using Equation (4) with the operating point computed in Step 1 above for:

a. The long term 1 inear regression curve for collector array efficiency

b. The laboratory single panel collector efficiency curve

3. The efficiencies computed in Steps $2 a$ and $2 b$ above were multiplied by the measured solar energy available when the collectors were operational to give two predicted values of solar energy collected.

The error data in Table 3.2.1-2 were computed from the differences between the measured and predicted values of solar energy collected according to the equation: 
TABLE 3.2.1-2

ENERGY GAIN COMPARISON

(ANNUAL)

SITE: IBM SYSTEM 2

TOGUS, MAINE

\begin{tabular}{|c|c|c|c|}
\hline \multirow[b]{2}{*}{ MONTH/YEAR } & \multirow{2}{*}{$\begin{array}{l}\text { COLLECTED } \\
\text { SOLAR ENERGY } \\
\text { (iNILLION BTU) }\end{array}$} & \multicolumn{2}{|c|}{ ERROR } \\
\hline & & $\begin{array}{c}\text { FIELD DERIVED } \\
\text { LONG TERM } \\
\end{array}$ & $\begin{array}{r}\text { LAB } \\
\text { PANEL } \\
\end{array}$ \\
\hline JAN 79 & 0.326 & -0.041 & 1.553 \\
\hline FEB 79 & 0.827 & -0.025 & 1.585 \\
\hline MAR 79 & 0.677 & 0.006 & 1.656 \\
\hline APR 79 & 0.854 & 0.180 & 2.140 \\
\hline MAY 79 & - & - & $\ldots$ \\
\hline JUN 78 & 1.356 & 0.606 & 3.629 \\
\hline JUL 78 & 1.206 & 0,038 & 1.772 \\
\hline$\therefore \quad$ AUG 78 & 0.971 & -0.012 & 1.672 \\
\hline SEP 78 & 1.194 & 0.046 & 1.640 \\
\hline OCT 78 & 0.354 & 0.034 & 1.652 \\
\hline NOV 78 & 0.033 & 0.041 & 1.480 \\
\hline DEC 78 & 0.503 & 0.106 & 1.830 \\
\hline AVERAGE & & 0.132 & $2: 043$ \\
\hline
\end{tabular}




$$
\text { Error }=:(A-P) / P
$$

where $\quad \begin{aligned} & A=\text { Measured solar energy collected } \\ & P=\text { Predicted solar energy collected }\end{aligned}$

The computed error is then an indication of how well the particular prediction curve fitted the reality of dynamic operating conditions in the field.

The values of "Collected Solar Energy" given in Table 3.2.1-2 are not necessarily identical with the values of "Collected Solar Energy" given in Table 3.2.1-1. Any variations are due to the differences in data processing between the software programs used to generate the monthly performance assessment data and the component level collector analysis program. These data are shown in Table 3.2.1-2 only because they form the references from which the error data given in the table are computed.

A histogram of collector array operating points illustrates the distribution of instantaneous values as determined by Equation (3) for the entire month. The histogram was constructed by computing the instantaneous operating point value from site instrumentation measurcments at the regular data system intervals thrinughout the month, and counting the number of values within contiguous intervals of width 0.01 from zero to unity. The operating point histogram shows the dynamic range of collector operation during the month from which the midpoint can be ascertained. The average collector array efficiency for the month can be derived by projecting the midpoint value to the appropriate efficiency curve and reading the corresponding value of efficlency.

Another characteristic of the operating point histogram is the shifting of the distribution along the operating point axis. This can be explained in terms of the characteristics of the system and the climatic factors 
of the site, i.e., incident solar energy and ambient temperature. Figure 3.2.1-3 shows two histograms that illustrate a typical winter month (February) and a typical summer month (August) operation. The actual midpoint which represents the average operating point for February is at 0.38 and for August at 0.29. From Equation (3) when the temperature difference becomes larger due to the lower $T_{a}$ and the incident solar energy becomes smaller, as is typical in the winter, the operating point increases and collector operation shifts to the right on the operating point histogram. The opposite situation occurs in the summer. The important point to be made from this is that the average collector efficiency, which depends on the operating point, shifts from winter to summer, assuming the higher value in the summer. The behavior is further illustrated by considering the data in Table $3.2 .1-1$.

The closed collector loop with silicone fluid forced the operating point to generally be between 0.29 and 0.38 . This grouping of data points resulted in larger energy gain comparison error on a monthly basis as shown in Figure 3.2.1-2. Over the full year this error averaged out and allowed the long term field data curve and the laboratory panel data curve to agree very well.

Table 3.2.1-1 presents the monthly values of incident solar energy, operational incident solar energy, and collected solar energy from the 12 month performance period. The collector array efficiency and operational collector array efficiency were computed for each month using Equations (1) and (2). The values of operational collector efficiency range from a maximum of 0.39 in July ' 79 to a minimum of 0.30 in February '79. On the average the operational collector array efficiency exceeded the collector array efficiency which included the effect of the control system by 13 percent. This represents good performance for these collectors in this application. 


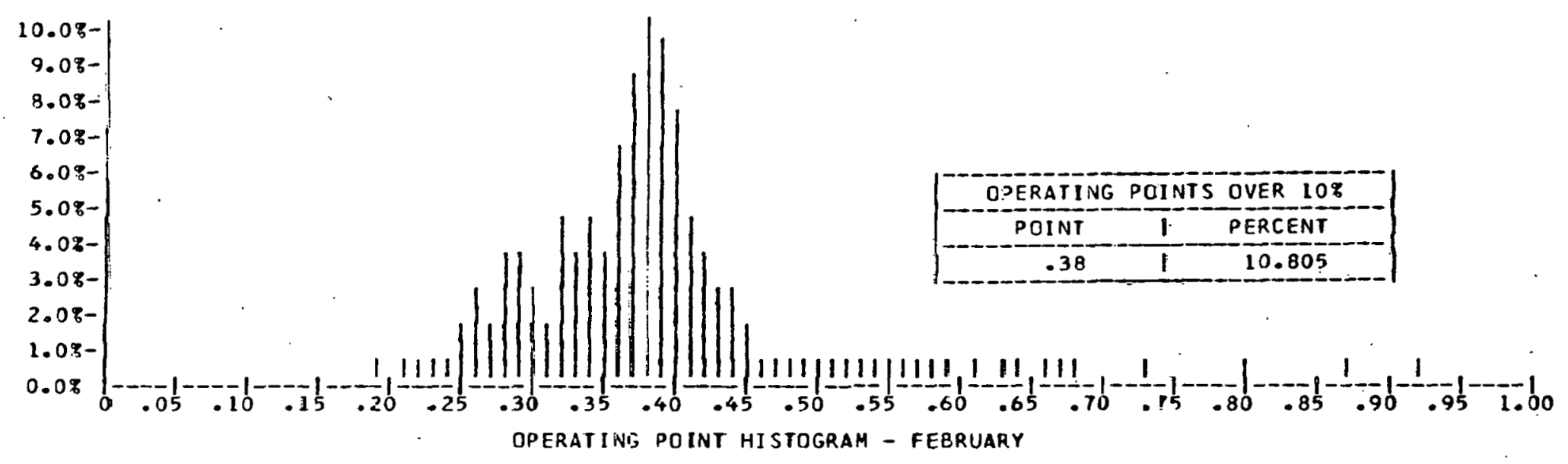

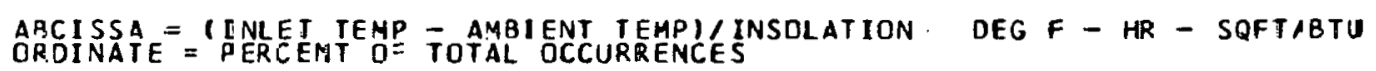

I:BM - $2 A$

COLLECTOR TYPE: L. O. F.

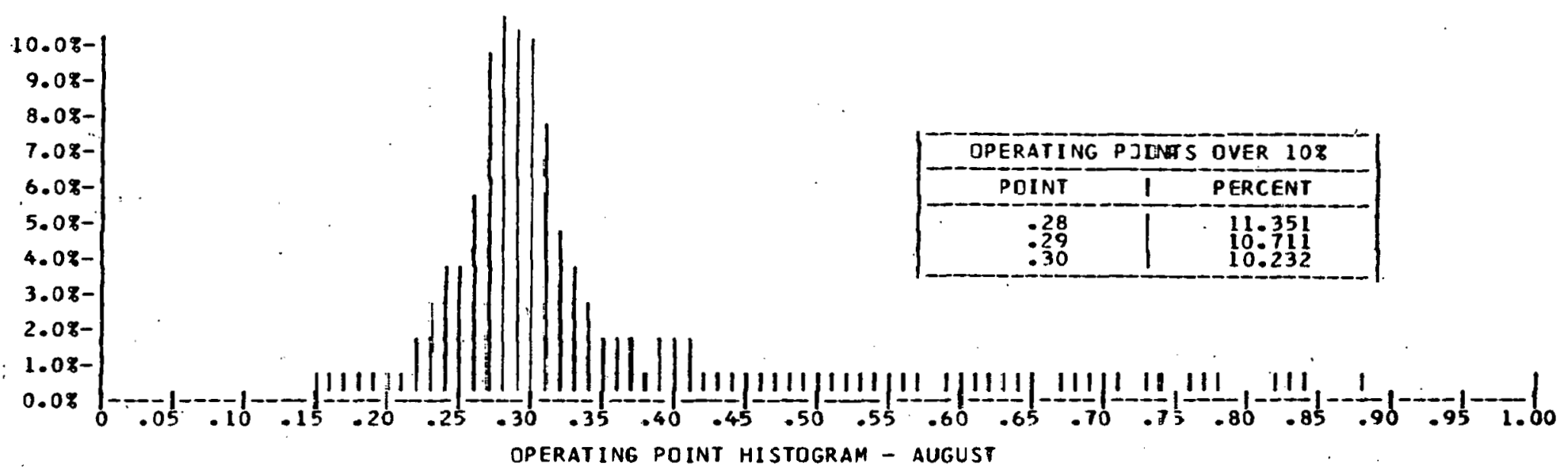

TOGUS, ME COLLECTOR MODEL: 1112

ABCISSA = IINLET TEMP - AMBIENT TEMPI'INSOLATION DEG F - HR - SOFTIETU

Figure 3.2.1-3 IBM System 2 Operating Point Histograms for Typical Winter and Summer Months 
Additional information concerning collector array analys is in general may be found in Reference [10]. The material in the reference describes the detailed collector array analysis procedures and presents the results of analyses performed on numerous collector array installations across the United States. 


\subsubsection{Storage Subsystem}

Storage subsystem performance is described by comparison of energy to storage, energy from storage and change in stored energy. The ratio of the sum of energy from storage and change in s.tored energy to energy to storage is defined as storage efficiency, $n_{s}$. This relationship is expressed in the equation

$$
n_{s}=\left(\Delta Q+Q_{s o}\right) / Q_{s i}
$$

where:

$\Delta Q \Rightarrow$ Change in stored energy. This is the difference in the estimated stored energy during the specified reporting period, as indicated by the relative temperature of the storage medium (either positive or negative value)

$Q_{\text {so }}=$ Energy from storage. This is the amount of energy extracted by the load subsystem from the primary storage medium

$Q_{s i}=$ Energy to storage. This is the amount of energy (both solar and auxiliary) delivered to the primary storage medium

Evaluation of the system storage performance under actual system operation and weather conditions can be performed using the parameters defined above. The utility of these measured data in evaluation of the overall storage design are illustrated in the following discussion.

The eleven month average storage efficiency was greater than 100 percent. This indicates that more heat energy was gained than lost from the subsystem. During the summer months storage efficiency averaged near 80 percent. This summer storage efficiency is more typical of systems of this type. 
TABLE 3.2.2-1

STORAGE SUBSYSTEM PERFORMANCE

\begin{tabular}{|c|c|c|c|c|c|}
\hline Month & $\begin{array}{l}\text { Energy To } \\
\text { Storage } \\
\text { (Million Btu) }\end{array}$ & $\begin{array}{l}\text { Energy From } \\
\text { Storage } \\
\text { (Million Btu) }\end{array}$ & $\begin{array}{l}\text { Change In } \\
\text { Stored } \\
\text { Energy } \\
\text { (Million Btu) }\end{array}$ & $\begin{array}{l}\text { Storage } \\
\text { Efficiency }\end{array}$ & $\begin{array}{c}\text { Storage } \\
\text { Average } \\
\text { Temperature } \\
\left({ }^{\circ} \mathrm{F}\right)\end{array}$ \\
\hline May 78 & 1.06 & 1.06 & 0.03 & 1.03 & 110 \\
\hline Jun 78 & $\star 0.91$ & 0.68 & 0.03 & $\star 0.75$ & 120 \\
\hline JuT 78 & $* 1.34$ & 1.07 & -0.01 & $\star 0.80$ & 127 \\
\hline Aug 78 & 0.77 & 0.63 & -0.02 & 0.80 & 126 \\
\hline Sep 78 & 0.90 & 0.94 & 0.01 & 1.06 & 124 \\
\hline Oct 78 & 0.77 & 0.77 & -0.05 & 1.00 & 111 \\
\hline Nov 78 & -- & -- & -- & -- & -- \\
\hline Dec 78 & 0.71 & 0.77 & 0.02 & 1.12 & 89 \\
\hline Jan 79 & 0.34 & 0.66 & -0.04 & 1.83 & 74 \\
\hline Feb 79 & .0 .85 & 0.96 & 0.05 & 1.20 & 96. \\
\hline Mar 79 & 0.70 & 1.06 & -0.03 & 1.47 & 92 \\
\hline Apr 79 & 0.91 & 0.85 & 0.02 & 0.96 & 103 \\
\hline Total & 9.26 & 9.45 & -- & -- & -- \\
\hline Average & 0.84 & 0.86 & -- & 1.09 & 107 \\
\hline
\end{tabular}

*T350 (Temperature of water to storage) sensor bad June 16-August 1 , an average value assumed for month. 
The oil-fired furnace discussed in Section 3.1 is suspected of providing the extra energy to the preheat tank. The furnace provided a warm basement ambient approximately 9 months out of the year. 


\subsubsection{Hot Water Subsystem}

The performance of the hot water subsystem is described by comparing the amount of solar energy supplied to the subsystem with the energy required to satisfy the total hot water load. The energy required to satisfy the total load consists of both solar energy and auxiliary thermal energy. The ratio of solar energy supplied to the load to the total load is defined as the hot water solar fraction. The calculated hot water solar fraction is the indicator of performance of the subsystem because it defines the percentage of the total hot water load supported by solar energy.

The performance of the IBM System 2 hot water subsystem is presented in Table 3.2.3-1. The value for auxiliary energy supplied in Table 3.2.3-1 gross energy supplied to the auxiliary system. The value of auxiliary energy supplied multiplied by the auxiliary system efficiency gives the auxiliary thermal energy actually delivered to the load. The difference between the sum of auxiliary. thermal energy plus solar energy and the hot water load is equal to the thermal losses from the hot water subsystem.

The measured solar fraction in Table 3.2.3-1 is an average weighted the month based on the ratio of solar energy in the hot water tank to the total energy in the hot water tank when a demand for hot water exists. This value is dependent on the daily profile of hot water usage. It does not represent the ratio of solar energy supplied to the sum of solar plus auxiliary energy supplied shown in the Table.

For the eleven-month period from May 1978 to April 1979 (excluding November due to data system problem), the solar energy system supplied a total of 9.45 million Btu to the hot water load. The total hot water load for this period was 13.42 million Btu, and the average monthly solar fraction was 51 percent. The average daily hot water usage was 56 gallons per day at an average temperature of $136^{\circ} \mathrm{F}$. 
TABLE 3.2.3-1

.

\begin{tabular}{|c|c|c|c|c|c|c|c|c|}
\hline \multirow[b]{2}{*}{ Month } & \multirow{2}{*}{\multicolumn{3}{|c|}{$\begin{array}{r}\text { Energy Supplied } \\
\text { (mi11,ion Btu) } \\
\end{array}$}} & \multicolumn{3}{|c|}{ Hot Water Parameters } & \multirow{2}{*}{$\begin{array}{l}\text { Standby } \\
\text { Losses } \\
\text { (million Btu) }\end{array}$} & \multirow{2}{*}{$\begin{array}{l}\text { Weighted* } \\
\text { Solar } \\
\text { Fraction } \\
\text { (Percent) }\end{array}$} \\
\hline & & & & $\begin{array}{c}\text { Average } \\
\text { Daily Gallons } \\
\text { Used }\end{array}$ & $\begin{array}{l}\text { Average } \\
\text { Supply Water } \\
\left.\text { Temp ( }{ }^{\circ} \mathrm{F}\right)\end{array}$ & $\begin{array}{c}\text { Loac } \\
\text { (millicr } \\
\text { Btu) }\end{array}$ & & \\
\hline May 78 & 1.32 & 1.06 & 2.38 & 60 & 52 & 1.55 & 0.83 & 46 \\
\hline Jun 78 & 0.75 & 0.68 & 1.43 & 38 & 53 & $0 . \varepsilon 7$ & 0.56 & 48 \\
\hline JuT 78 & 0.76 & 1.07 & 1.83 & 59 & 62 & 1.11 & 0.72 & 58 \\
\hline Aug 78 & 0.57 & 0.53 & 1.20 & $3 \varepsilon$ & 64 & 0.71 & 0.49 & 55 \\
\hline Sep 78 & 0.74 & 0.94 & 1.68 & 50 & 62 & 1.06 & 0.62 & 62 \\
\hline Oct 78 & 0.91 & 0.77 & 1.68 & $5 \subseteq$ & 60 & 1.14 & 0.54 & 54 \\
\hline Nov 78 & -- & -- & -- & - & -- & $\therefore$ & -- & -. \\
\hline Dec 78 & 1.31 & 0.77 & 2.08 & 58 & 47 & 1.32 & 0.76 & 46 \\
\hline $\operatorname{Jan} 79$ & 1.51 & 0.66 & 2.17 & 62 & 43 & 1.45 & 0.71 & 38 \\
\hline Feb 79 & 1.19 & 0.96 & 2.15 & 63 & 41 & 1.33 & 0.77 & 51 \\
\hline Mar 79 & 1.44 & 1.06 & 2.50 & 66 & 42 & $1.6 ?$ & 0.88 & 49 \\
\hline Apr 79 & 1.08 & 0.85 & 1.93 & 52 & 42 & 1.23 & 0.73 & 50 \\
\hline Total & 11.58 & 9.45 & 21.33 & -- & -- & $13.4 ?$ & $7: 61$ & -- \\
\hline Average & 1.05 & 0.86 & 1.91 & 56 & 52 & 1.22 & 0.69 & 51 \\
\hline
\end{tabular}




\section{OPERATING ENERGY}

Operating energy for the IBM-System 2 Solar Energy System is defined as the energy required to transport solar energy to the point of use. Total operating energy for this system consists of the energy required to operate two small pumps. One pump circulates the silicone fluid through the collector loop and one side of the heat exchanger. The other pump circulates water from the preheat tank through the heat exchanger. Operating energy is electrical energy. Measured monthly values for subsystem operating energy are presented in Table 4-1. For the May 1978 through April 1979 period covered by this report a total of 1.25 million Btu of operating energy was consumed. During the same time a total of 9.45 million Btu of solar energy was supplied to the total system load. Therefore, for every one million Btu of solar energy delivered to the load, $0.13 \mathrm{million}$ Btu (or $38 \mathrm{kwh}$ ) of electrical operating energy was expended. 
TABLE 4-1

OPERATING ENERGY

\begin{tabular}{|c|c|c|c|}
\hline Month & $\begin{array}{l}\text { ECSS } \\
\text { Operating Energy } \\
\text { (Million Btu) } \\
\end{array}$ & $\begin{array}{c}\text { Hot Water } \\
\text { Operating Energy } \\
\text { (Miltion Btu) }\end{array}$ & $\begin{array}{c}\text { Total System } \\
\text { Operating Energy } \\
\text { (Milioion Btu) } \\
\end{array}$ \\
\hline May 78 & \multicolumn{2}{|c|}{ [MEASURED TOGETHER] } & 0.14 \\
\hline Jun 78 & \multicolumn{2}{|c|}{ [MEASURED TOGETHER] } & 0.11 \\
\hline Ju1 78 & \multicolumn{2}{|c|}{ [MEASURED TOGETHER] } & 0.16 \\
\hline Aug 78 & \multicolumn{2}{|c|}{ [MEASURED TOGETHER] } & 0.13 \\
\hline Sep 78 & \multicolumn{2}{|c|}{ [MEASURED TOGETHER] } & 0.15 \\
\hline Oct 78 & \multicolumn{2}{|c|}{ [MEASURED TOGETHER] } & 0.10 \\
\hline Nov 78 & \multicolumn{2}{|c|}{ [MEASURED TOGETHER] } & -- \\
\hline Dec 78 & \multicolumn{2}{|c|}{ [MEASURED TOGETHER] } & 0.09 \\
\hline Jan 79 & \multicolumn{2}{|c|}{ [MEASURED TOGETHER] } & 0.05 \\
\hline Feb 79 & \multicolumn{2}{|c|}{ [MEASURED TOGETHER] } & 0.11 \\
\hline Mar 79 & \multicolumn{2}{|c|}{ [NEASURED TOGETHER] } & 0.10 \\
\hline Apr 79 & \multicolumn{2}{|c|}{ [MEASURED TOGETHER] } & 0.11 \\
\hline Total & \multicolumn{2}{|c|}{ [MEASURED TOGETHER] } & 1.25 \\
\hline Average & \multicolumn{2}{|c|}{ [MEASURED TOGETHER] } & 0.11 \\
\hline
\end{tabular}




\section{ENERGY SAVINGS}

Solair energy system savings are realized whenever energy provided by the solar energy system is used to meet system demands which would otherwise be met by auxiliary energy sources. The operating energy required to provide solar energy to the load subsystems is subtracted from the solar energy contribution, and the resulting energy savings are adjusted to reflect the coefficient of performance (COP) of the auxiliary source being supplanted by solar energy.

Energy savings for May 1978 through April 1979 are presented in Table 5-1. For this time period, the average gross monthly savings were 0.86 million Btu. After the Energy Collection and Storage Subsystem (ECSS) operating energy was deducted, the average net monthly electrical savings were approximately 0.75 million Btu, or $220 \mathrm{kwh}$. For the overall time period covered by this report the total net savings were $8.21 \mathrm{mil}$ lion Btu, or 2406 kwh. 
TARLE 5-1

ENERGY SAVINGS

\begin{tabular}{|c|c|c|c|c|}
\hline \multirow[b]{2}{*}{ Month } & \multirow{2}{*}{$\begin{array}{c}\text { Electrical Energy javings } \\
\text { (Million Btu) } \\
\text { Hot } \\
\text { Hater } \\
\end{array}$} & \multirow{2}{*}{$\begin{array}{l}\text { ECSS } \\
\text { Operating } \\
\text { Energy } \\
\text { (Million Btu) } \\
\end{array}$} & \multicolumn{2}{|c|}{$\begin{array}{l}\text { Net Szvings } \\
\text { Electrical }\end{array}$} \\
\hline & & & $\begin{array}{l}\text { Million } \\
\text { Btl }\end{array}$ & kwh \\
\hline May 78 & 1.06 & 0.14 & 0.93 & 273 \\
\hline Jun 78 & 0.67 & 0.11 & 0.57 & 167 \\
\hline Jul 78 & 1.07 & 0.16 & 0.92 & 270 \\
\hline Aug 78 & 0.63 & 0.13 & 0.50 & 147 \\
\hline Sep 78 & 0.94 & 0.15 & 9.79 & 231 \\
\hline Oct 78 & 0.77 & 0.10 & D.E6 & 193 \\
\hline Nov 78 & -- & -- & -- & -- \\
\hline Dec 78 & 0.77 & 0.09 & 0.67 & 196 \\
\hline Jan 79 & 0.66 & 0.05 & 0.67 & 179 \\
\hline Feb 79 & 0.96 & 0.11 & 0.85 & 249 \\
\hline Mar. 79 & 1.06 & 0.10 & 0.97 & 284 \\
\hline Apr 79 & 0.85 & 0.11 & 0.74 & 217 \\
\hline Total & 9.45 & 1.25 & 8.21 & 2,406 \\
\hline Average & 0.86 & 0.11 & 0.75 & 219. \\
\hline
\end{tabular}




\section{MAINTENANCE}

No maintenance was required for IBM-System 2 during the 12 months that data was taken. 


\section{SUMMARY AND CONCLUSIONS}

This System Performance Evaluation report provides an operational summary of a solar energy system installed in a single family dwelling at the VA Hospital in Togus, Maine. This analysis was conducted by evaluation of measured system performance and by comparison of measured climatic data with long-term average climatic conditions.

Monthly values of average daily insolation and average ambient temperature measured at the IBM-System 2 site are presented in Table 3.1-1. Also presented in the table are the long term, average monthly values for these cilmatic paramezers. Ine long-term data are taken from Ref. [1] of Appendix C. Data was taken from May 1978 through April 1979 (except for November 1978). November data was not collected due to a data system problem.

Measured solar insolation was $14 \%$ less than expected for the year while the average temperature was as expected. Most of the abnormally cloudy weather occurred in October 1978, January 1979, and March 1979.

The yearly collector array efficiency based on total incident solar energy was 22 percent. The efficiency based on operational incident solar energy was 35 percent. The colllector subsystem performed as expected with very little if any degradation.

Approximately 0.75 million Btu of auxiliary energy was saved during an average month. This converts to $220 \mathrm{kwh}$ of electricity per month average savings:

During June 1978 the DHW heater thermostat was lowered from $150^{\circ}$ to $134^{\circ} \mathrm{F}$ while the preheat tank cutoff was raised from $140^{\circ}$ to $160^{\circ} \mathrm{F}$. These set points were not changed again, since they proved to be acceptable to both solar and auxiliary. From the time of the tank set point change through April 1979, the weighted average solar fraction was 51 percent compared to 40-50 percent before the change. Therefore, just over 50 percent of the hot water energy consumed at the house was supplied by solar. 
The daily hot water usage was very consistent, averaging $60 \mathrm{gal} / \mathrm{day}$ for the time the house was occupied. No hot water was used for approximately a week each time during three months (June and August 1978 and Apri1 1979).

The system performed consistently well with no down time. The weather and hot water load were close to expected values. As a result, the over-all system performance of the year was very close to predicted values. 


\section{REFERENCES}

1. DOE/NASA CR-150521, System Design Package for SIMS Prototype System 2, Solar Hot Water, Dec. 1977.

2. DOE/NASA CR-150558, Design Data Brochure SIMS Prototype System 2, Dec. 1977.

3. DOE/NASA CR-150639, Installation Package for SIMS Prototype System 2, Solar Hot Water, Jan. 1978.

4. E. Streed, etc. al., Thermal Data Requirements and Performance Evaluation Procedures for the National Solar Heating and Cooling Deimonstration Program, NBS-IR- $/ 8-1137$, National Bureau of Standards, Washing̣tón, August, 1976.

5. J. T. Smok, V. S. Sohoni, J. M. Nash, "Processing of Instrumented Data for the National Solar Heating and Cooling Demonstration Program," Conference on Performance Monitoring Techniques for Evaluation of Solar Heating and Cooling Systems, Washington, D.C., April, 1978.

6. ASHRAE Standard 93-77, Methods of Testing to Determine the Thermal Performance of Solar ColTectors, The American Society of Heating, Refrigeration and Air Conditioning Engineers, Inc., New York, NY, 1977.

7. ASHRAE Standard 94-77, Methods of Testing Thermal Storage Devices Based on Thermal Performance, The American Society of Heating Refrigeration and Air Conditioning Engineers, Inc., New York, NY, 1977.

8. Beckman, William A.; Klein, Sanford A.; Duffie, John A., Solar Heating Design by the f-Chart Method, John Wiley and Sons, New York, 1977.

9. DOE/NASA CR-150544, SIMS Prototype System 2 Test Results Engineering Analysis, January 7078.

10. McCumber, W. H. Jr., "Collector Array Performance for Instrumented Sites of the Natinnal Snlar Heating and Cooling Demonstration Program," to be published and distributed at the 1979 Solar Update Conference. 
APPENDIX A

DEFINITION OF PERFORMANCE FACTORS AND SOLAR TERMS

A-1 


\author{
APPENDIX A \\ DEFINITION OF PERFORMANCE FACTORS AND SOLAR TERMS
}

\title{
COLLECTOR ARRAY PERFORMANCE
}

The collector array performance is characterized by the amount of solar energy collected with respect to the energy available to be collected.

- INCIDENT SOLAR ENERGY (SEA) is the total insolation available on the gross coliector array area. This is the area of the collector array energy-receiving aperture, including the framework which is an integral part of the collector structure.

- OPERATIONAL INCIDENT ENERGY (SEOP) is the amount of solar energy incident on the collector array during the time that the collector loop is active (attempting to collect energy).

- COLLECTED SOLAR ENERGY (SECA) is the thermal energy removed from the collector array by the energy transport medium.

- COLLECTOR ARRAY EFFICIENCY (CAREF) is the ratio of the energy collested to the total solar energy incident on the collector array. It should be emphasized that this efficiency factor is for the r.ollector array, and available energy includes the energy incident on the array when the collector loop is inactive. This efficiency must not be confused with the more common collector efficiency figures which are determined from instantaneous test data obtained during steady state operation of a single collector unit. These efficiency figures are often provided by collector manufacturers or presented in tecinical journals to characterize the functional capability of a particular collector design. In general, the collector panel maximum efficiency factor will be significantly higher than the collector array efficiency reported here. 
The storage performance is characterized by the relationships among the energy delivered to storage, removed from storage, and the subsequent change in the amount of stored energy.

- ENERGY TO STORAGE (STEI) is the amount of energy, both solar and auxiliary, delivered to the primary storage medium.

- ENERGY FROM STORAGE (STEO) is the amount of energy extracted by the load subsystems from the primary storage medium.

0 CHANGE IN STORED ENERGY (STECH) is the difference in the estimated stored energy during the specified reporting period, as indicated by the relative temperature of the storage medium (either positive or negative value).

- STORAGE AVERAGE TEMPERATURE (TST) is the mass-weighted average temperature of the primary storage medium.

- STORAGE EFFICIENCY (STEFF) is the ratio of the sum of the energy removed from storage and the change in stored energy to the energy delivered to storage. 


\section{ENERGY COLLECTION AND STORAGE SUBSYSTEM}

The Energy Collection and Storage Subsystem (ECSS) is composed of the collector array, the primary storage medium, the transport loops between these, and other components in the system design which are necessary to mechanize the collector and storage equipment.

- INCIDENT SOLAR ENERGY (SEA) is the total insolation available on the gross collector array area. This is the area of the collector array energy-receiving aperture, including the framework which is an integral part. of the collector structure.

- AMBIENT TEMPERATURE (TA) is the average temperature of the outdoor environment at the site.

- ENERGY TO LOADS (SEL) is the total thermal energy transported from the ECSS to all load subsystems.

- AUXILIARY THERMAL ENERGY TO ECSS (CSAUX) is the total auxiliary supplied to the ECSS, including auxiliary energy added to the storage tank, heating devices on the collectors for freezeprotection, etc.

- ECSS OPERATING ENERGY (CSOPE) is the critical operating energy required to support the ECSS heat transfer loops. 
The hot water subsystem is characterized by a complete accounting of the energy flow into and from the subsystem, as well as an accounting of internal energy. The energy into the subsystem is composed of auxiliary fossil fuel, and electrical auxiliary thermal energy, and the operating energy for the subsystem. In addition, the solar energy supplied to the subsystem, along with solar fraction is tabulated. The load of the subsystem is tabulated and used to compute the estimated electrical and fossil fuel savings of the subsystem. The load of the subsystem is further identified by tabulating the supply water temperature, and the outlet hot water temperature, and the total hot water consumption.

- HOT WATER LOAD (HWL) is the amount of energy required to heat the amount of hot water demanded at the site from the incoming temperature to the desired outlet temperature.

- SOLAR FRACTION OF LOAD (HWSFR) is the percentage of the load demand which is supported by solar energy.

- SOLAR ENERGY USED (HWSE) is the amount of solar energy supplied to the hot water subsystem.

- OPERATING ENERGY (HWOPE) is the amount of electrical energy required to support the subsystem, (e.g., fans, pumps, etc.) and which is not intended to affect directly the thermal state of the subsystem.

- AUXILIARY THERMAL USED (HWAT) is the amount of energy supplied to the major components of the subsystem in the form of thermal energy in a heat transfer fluid, or its equivalent. This term also includes the converted electrical and fossil fuel energy supplied to the subsystem. 
- AUXILIARY ELECTRICAL FUEL (HWAE) is the amount of electrical energy supplied directly to the subsystem.

- ELECTRICAL ENERGY SAVINGS (HWSVE) is the estimated difference between the electrical energy requirements of an alternative conventional system (carrying the full load) and the actual electrical energy required by the subsystem.

- SUPPLY WATER TEMPERATURE (TSW) is the average inlet temperature of the water supplied to the subsystem.

- AVERAGE HOT WATER TEMPERATURE (THW) is the average temperature of the outlet water as it is supplied from the subsystem to the load.

- HOT WATER USED (HWCSM) is the volume of water used. 
The environmental summary is a collection of the weather data which is generally instrumented at each site in the program. It is tabulated in this data report for two purposes--as a measure of the conditions prevalent during the operation of the system at the site, and as an historical record of weather data for the vicinity of the site.

- TOTAL INSOLATION (SE) is accumulated total solar energy incident upon the gross collector array measured at the site.

- AMBIENT TEMPERATURE (TA) is the average temperature of the environment at the site.

- DAYTIME AMBIENT TEMPERATURE (TDA) is the temperature during the period from three hours before solar noon to three hours after solar noon. 
APPENDIX B

SOLAR ENERGY SYSTEM PERFORMANCE EQUATIONS 
APPENDIX B

SOLAR ENERGY SYSTEM PERFORMANCE EQUATIONS FOR

IBM SYSTEM 2

\section{INTRODUCTION}

Solar energy system performance is evaluated by performing energy balance calculations on the system and its major subsystems. These calculations are based on physical measurement data taken from each subsystem every 320 secunds. This data is then numerically combined to determine the hourly, daily, and monthly performance of the system. This appendix describes the general computational methods and the specific energy balance equations used for this evaluation.

Data samples from the system measurements are numerically integrated to provide discrete approximations of the continuous functions which characterize the system's dynamic behavior. This numerical integration is performed by summation of the product of the measured rate of the appropriate performance parameters and the sampling interval over the total time period of interest.

There are several general forms of numerical integration equations which are applied to each site. These general forms are exemplified as follows: The total solar energy available to the collector array is given by

$$
\text { SOLAR ENERGY AVAILABLE }=(1 / 60) \Sigma \quad[1001 \times \text { AREA }] \times \Delta \tau
$$

Where 1001 is the solar radtation measurement provided by the pyranometer in Btu/ft $\mathrm{ft}^{2}-\mathrm{hr}$, AREA is the area of the collector array in square feet, $\Delta \tau$ is the sampling interval in minutes, and the factor (1/60) is included to correct the solar radiation "rate" to the proper units of time. 
Similarly, the energy flow within a system is given typically by

COLLECTED SOLAR ENERGY $=\Sigma[M 100 \times \Delta H] \times \Delta T$

where $M 100$ is the mass flow rate of the heat transfer fluid in $1 b_{m} /$ min and $\Delta H$ is the enthalpy change, in $B t u / I b_{m}$, of the fluid as it passes through the heat exchanging component.

For a liquid system $\Delta H$ is generally given by

$$
\Delta H=\bar{C}_{p} \Delta T
$$

where $\bar{C}_{p}$ is the average specific heat, in $B t u /\left(1 b_{m}-{ }^{-} F\right)$, of the heat transfer fluid and $\Delta T$, in ${ }^{\circ} \mathrm{F}$, is the temperature differential across the heat exchanging component.

For an air system $\Delta H$ is generally given by

$$
\Delta H=H_{a}\left(T_{\text {out }}\right)-H_{a}\left(T_{\text {in }}\right)
$$

where $H_{a}(T)$ is the enthalpy, in $B t u / 1 b_{m}$, of the transport air evaluated at the inlet and outlet temperatures of the heat exchanging component.

$H_{a}(T)$ can have various forms, depending on whether or not the humidity ratio of the transport air remains constant as it passes through the heat exchanging component. 
For electrical power, a general example is

$$
\text { ECSS OPERATING ENERGY }=(3413 / 60) \Sigma[\text { [EP100] } \times \Delta \tau
$$

where EP100 is the power required by electrical equipment. in kilowatts and the two factors $(1 / 60)$ and 3413 correct the data to Btu/min.

These equations are comparable to those specified in "Thermal Data Requirements and Performance Evaluation Proccdures for the Natiuild 1 Solar Heating and Cooling Demonstration Program." This document, given in the list of references, was prepared by an inter-agency committee of the government, and presents guidelines for thermal performance evaluation.

Performance factors are computed for each hour of the day. Each numerical integration process, therefore, is performed over a period of one hour. Since long-term performance data is desired, it is necessary to build these hourly performance factors to daily values. This is accomplished, for energy parameters, by summing the 24 hourly values. For temperatures, the hourly values are averaged. Certain special factors, such as efidciencies, require appropriate handling to properily weight each hourly sample for the dafly value computation. Similar procedures are required to convert daily values to monthly values. 
EQUATIONS USED IN MONTHLY PERFORMANCE ASSESSMENTS

NOTE: - MEASUREMENT NUMBERS REFERENCE SYSTEM SCHEMATIC FIGURE 2-1

AVERAGE AMBIENT TEMPERATURE $\left({ }^{\circ} \mathrm{F}\right)$

$T A=(1 / 60) \times \sum T 001 \times \Delta \tau$

DAYTIME AVERAGE AMBIENT TEMPERATURE $\left({ }^{\circ} \mathrm{F}\right)$

$T D A=(1 / 360) \times \Sigma T 001 \times \Delta \tau$

FOR \pm 3 HOURS FROM SOLAR NOON

INCIDENT SOLAR ENERGY PER SQUARE FOOT (BTU/FT ${ }^{2}$ )

$S E=(1 / 60) \times \Sigma 1001 \times \Delta \tau$

OPERATIONAL INCIDENT SOLAR ENERGY (BTU)

SEOP $=(1 / 60) \times \Sigma[1001 \times$ CLAREA $] \times \Delta \tau$

WHEN THE COLLECTOR LOOP IS ACTIVE

SOLAR ENERGY COLLECTED BY THE ARRAY (BTU)

SECA $=\Sigma[M 100 \times C P 52 \times(T 150-T 100] \times \Delta \tau$ 
INCIDENT SOLAR ENERGY ON COLLECTOR ARRAY (BTU)

SEA $=$ CLAREA $\times$ SE

COLLECTED SOLAR ENERGY (BTU/FT'

SEC = SECA/CLAREA

COLLECTOR ARRAY EFFICIENCY

CAREF = SECA/SEA

CHANGE IN STORED ENERGY (BTU)

STECH = STECHT - STECHI $_{p}$

WHERE THE SUBSCRIPT $p$ REFERS TO A PRIOR REFERENCE VALUE

STORAGE EFFICIENCY

STEFF $=($ STECH + STEO $) /$ STEI

SOLAR ENERGY TO LOAD SUBSYSTEMS (BTU)

SEL $=$ CSEO

ECSS SOLAR CONVERSION EFFICIENCY

CSCEF $=$ SEL $/$ SEA

AUXILIARY THERMAL ENERGY TO HOT WATER SUBSYSTEM (BTU)

HWAT $=\quad$ HWAE

HOT WATER SOLAR FRACTION (PERCENT)

HWSFR $=100 \times \mathrm{HWTKSE} /$ (HWTKSE + HWTKAUX)

WHËRE HWTKSE AND HWTKAUX REPRESENT THE CURRENT SOLAR AND ÁUXILIARY ENERGY CONTENT OF THE HOT WATER TANK

HOT WATER ELECTRICAL ENERGY SAVINGS (BTU)

HWSVE = HWSE 
IF $\mathrm{M} 300-\mathrm{M} 301>0$

$$
\text { MSTEI }=\text { M300 - M301 }
$$

MSTEO $=0$

ELSE DO:

$$
\begin{aligned}
& \text { MSTEO }=\text { M301-M300 } \\
& \text { MSTEI }=0
\end{aligned}
$$

SOLAR ENERGY TO STORAGE (BTU)

$$
\text { STEI }=\Sigma[M S T E I * H W D(T 350, T 300)] \times \Delta \tau
$$

SOLAR ENERGY FROM STORAGE (BTU)

$$
\text { STEO }=\Sigma[M S T E O * H W D(T 351, T 301)] \times \Delta \tau
$$

AVERAGE TEMPEATURE OF STORAGE $\left({ }^{\circ} \mathrm{F}\right)$

$$
\text { TSTM }=(1 / 60) \times \Sigma[(T 303+T 304) / 2] \times \Delta \tau
$$

HOT WATER CONSUMED (GALLONS)

$H W C S M=\sum W D 301 \times \Delta \tau$

SUPPLY WATER TEMPERATURE $\left({ }^{\circ} \mathrm{F}\right)$

$T S W=T 301$

HOT WATER TEMPEATURE $\left({ }^{\circ} \mathrm{F}\right)$

$\mathrm{THW}=\mathrm{T} 352$

BOTH TSW AND THW ARE COMPUTED ONLY WHEN FLOW EXISTS IN THE SUBSYSTEM, OTHERWISE THEY ARE SET EQUAL TO THE VALUES OBTAINED DURING THE PREVIOUS FLOW PERIOD.

HOT WATER LOAD (BTU)

$H W L=\Sigma[M 30 \times H W D(T 352, T 301)] \times \Delta \tau$ 
APPENDIX C

LISTING OF MONTHLY ENVIRONMENTAL DATA 
APPENDIX C

\section{LONG-TERM AVERAGE WEATHER CONDITIONS}

The environmental estimates given in this appendix provide a point of reference for evaluation of weather conditions as reported in the Monthly Performance Assessments and Solar Energy System Performance Evaluations issued by the National Solar Data Program. As such, the information presented can be useful in prediction of long-term system performance.

Environmental estimates for this site include the followirly munthly averages: exiraterrestrial insolation, insolation on a horizontal plane at the site, insolation in the tilt plane of the collection surface, ambient temperature, heating degree-days, and cooling degree-days. Estimation procedures and data sources are detailed in the following paragraphs.

The preferred source of long-term temperature and insolation data is "Input Data for Solar Systems" (IDSS) [1] since this has been recognized as the solar standard. The IDSS data are used whenever possible in these environmental estimates for both insolation and temperature related sources; however, a secondary source used for insolarion data is the climatic Atlas of the United States [?], and for temperature related data, the secondary source is "Local Climatological Data" [3].

Since the available long-term insolation data are only given for a horizontal surface, solar collection subsystem orientation information is used in an algorithm [4] to calculate the insolation expected in the tilt plane of the collector. This calculation is made using a ground reflectance of 0.2 .

No listing for Togus, Maine is given in any of the preferred primary data sources. It is therefore necessary to interpolate among data given by nearby weather stations to derive an estimate. For insolation estimates, IDSS data from Bangor, Maine and Portland, Maine are used in the proportions of 0.4595 to 0.5405 , respectively. For temperature related estimates, IDSS data from Caribou, Maine and Portland, Maine are proportioned 0.2099 and 0.7901 . 
SITE: IBE TOGUS

\section{ANALYST:}

M. STRICKLAND.

COLLECTOR TILT: $\quad 45.00$ (DEGREES)

LATITUDE: $\quad 44.30$ (DEGREES)
38.

LOCATION: TOGUS

PDRIVE NO.: 63.

COLLECTOR AZIMUTH:

15.00 (DEGREES)

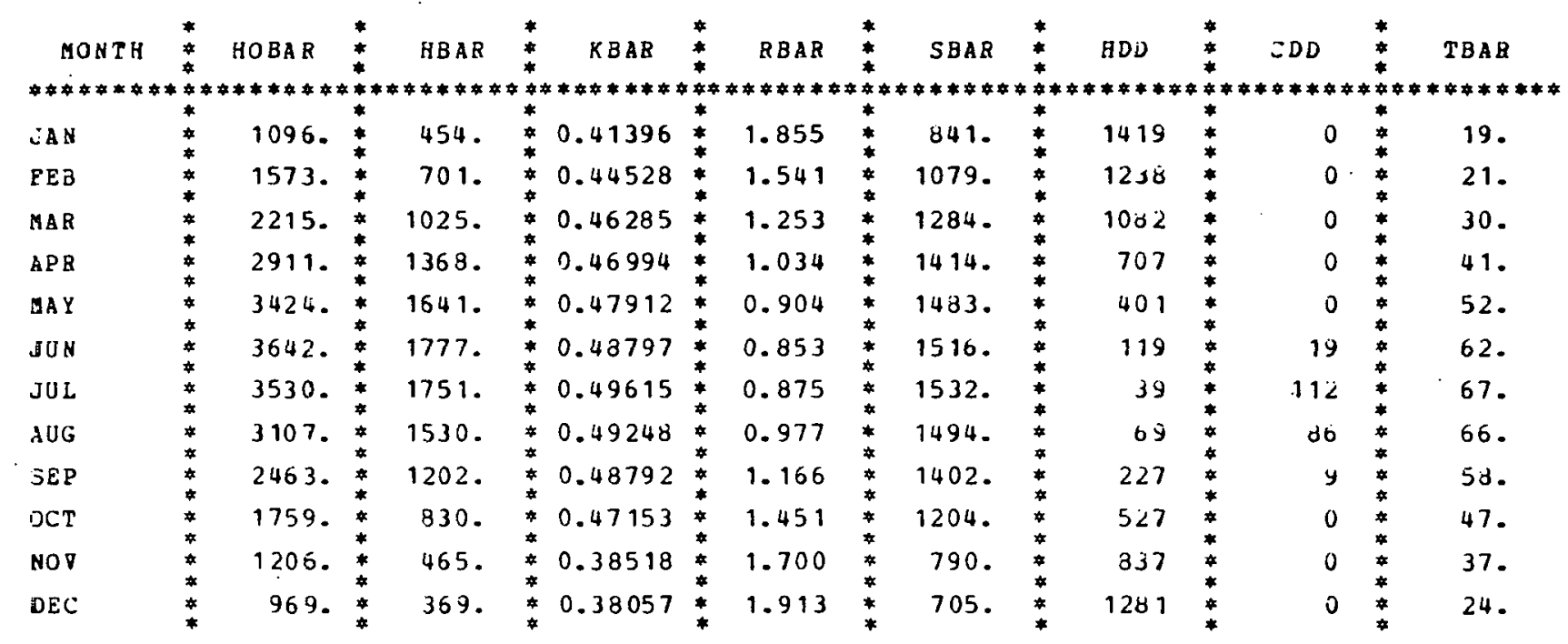

LEGEND :

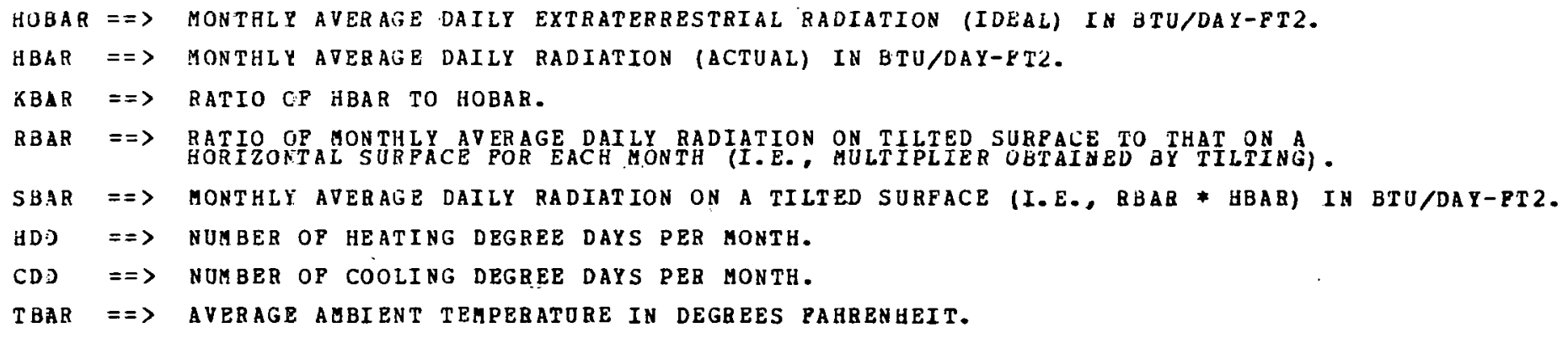


[1] Cinquemani, V., et. al., "Input Data for Solar Systems," Prepared for the U. S. Department of Energy by the National Climatic Center, Asheville, NC, 1978.

[2] United States Department of Commerce, Climatic Atlas of the United States, Environmental Data Service, Reprinted by the National Oceanic and Atmospheric Administratiun, Washington, DC, 1977.

[3] United States Department of Commerce, "Local Cl imatological Data," Environmental Data Service, National Oceanic and Atmospheric Administration, Asheville, NC, 1977.

[4] Klein, S. A., "Calculation of Monthly Average Insolation on Tilted Surfaces," Joint Conference 1976 of the International Solar Energy Society and the Solar Energy Society of Canada, Inc., Winnipeg, August $15-20,1976$. 